BULLETIN Bulletin hispanique

HISPANIQUE Université Michel de Montaigne Bordeaux

113-1 | 2011

Actes de 2 colloques

\title{
Los anuncios de impresos poéticos en la Gaceta de Madrid (1697-1750)
}

Jean-Marc Buiguès

\section{(2) OpenEdition}

Journals

Edición electrónica

URL: http://journals.openedition.org/bulletinhispanique/1361

DOI: 10.4000/bulletinhispanique.1361

ISSN: 1775-3821

Editor

Presses universitaires de Bordeaux

Edición impresa

Fecha de publicación: 1 junio 2011

Paginación: 331-366

ISBN: 978-2-86781-740-3

ISSN: 0007-4640

Referencia electrónica

Jean-Marc Buiguès, «Los anuncios de impresos poéticos en la Gaceta de Madrid (1697-1750) »,

Bulletin hispanique [En línea], 113-1 | 2011, Publicado el 01 junio 2014, consultado el 20 abril 2019.

URL : http://journals.openedition.org/bulletinhispanique/1361 ; DOI : 10.4000/bulletinhispanique.1361

Tous droits réservés 


\title{
Los anuncios de impresos poéticos en la Gaceta de Madrid (1697-1750)
}

\author{
JeAn-Marc Buigù̀s \\ Université Michel de Montaigne Bordeaux
}

Cet article analyse les annonces d'imprimés poétiques publiés dans la Gaceta de Madrid entre 1697 et 1750. En premier lieu, l'analyse porte sur le rythme de leurs publications et examine ensuite les annonces de poésie gréco-latine et de poésie religieuse.

Este artículo analiza los anuncios de impresos poéticos publicados en la Gaceta de Madrid entre 1697 y 1750. En primer lugar, el análisis se centra en el ritmo de sus publicaciones y luego en el examen de los anuncios de poesía greco-latina y de poesía religiosa.

The article analyzes the advertisements for poetic printed matter that were published in the Gaceta de Madrid between 1697 and 1750. The analyze is firstly about the rhythm of their publication, then about the advertisements in greco-latin poetry and religious poetry.

Mots-clés : Poésie - Post-baroque - Presse - Gaceta de Madrid - XVIII - Espagne.

Bulletin Hispanique, Tome 113, nº 1 - juin 2011 - p. 331 à 366. 
BULLETIN HISPANIQUE

In memoriam François Lopez

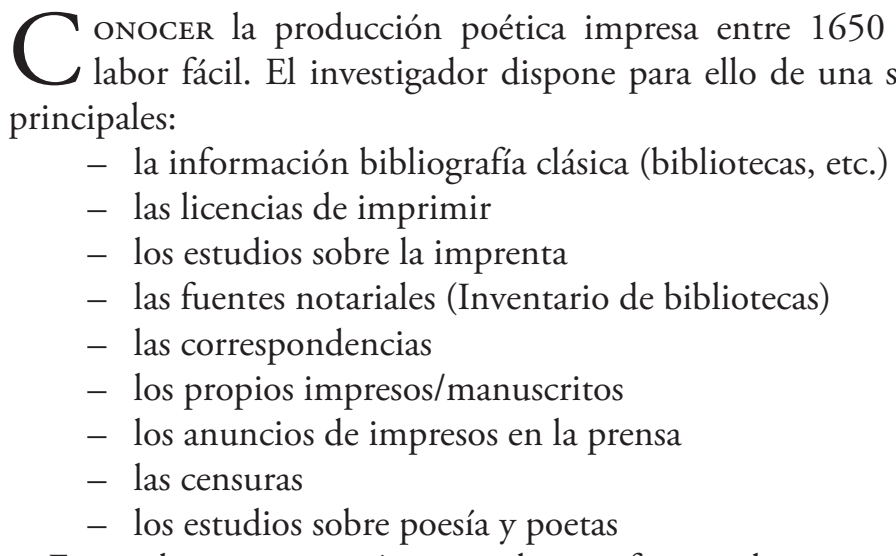

Este trabajo se centrará en una de estas fuentes, los anuncios de impresos poéticos en la prensa, y más precisamente en la Gaceta de Madrid. En la primera parte de este trabajo y a modo de introducción, presentaremos a grandes rasgos la Gaceta de Madrid ${ }^{1}$ y la base de datos de anuncios de impresos sobre la que radica nuestro análisis.

\section{LOS ANUNCIOS DE IMPRESOS EN LA GACETA DE MADRID: CONTENIDO Y RITMO DE PUBLICACIONES}

Entre los primeros impresos periódicos², la Gaceta de Madrid, después de varios intentos, consiguió a partir de 1697, fecha de su adquisición por Juan de Goyeneche, convertirse en una publicación de total continuidad

\footnotetext{
1. Después de los estudios pioneros de E. Hartzenbush (Apuntes para un catálogo de periódicos madrileños desde el año 1661 al 1870, Madrid, 1894) y de J. Pérez de Guzmán (Bosquejo histórico documental de la Gaceta de Madrid. Escrito al entrar en el siglo IV de su existencia y para solemnizar la declaración de la mayoría de edad del Rey D. Alfonso XIII, Madrid, Imprenta sucesora de M. Minuesa de los Ríos, 1909), fue Luis Miguel Enciso Recio quien volvió a estudiar la prensa dieciochesca con sus trabajos sobre Nipho (Nipho y el periodismo español del siglo XVIII, Valladolid, Ed. de la Universidad de Valladolid, 1956) y más precisamente sobre la Gaceta ( $L a$ Gaceta de Madrid y El Mercurio histórico y político, 1756-1791, Valladolid, Universidad de Valladolid, 1957).

2. Para una visión de conjunto, es de consulta imprescindible el estudio de Paul Guinard, La presse espagnole de 1737 à 1791. Formation et signification d'un genre, Paris, Institut d'Études Hispaniques, 1973 como también Isabelle Larriba, Le Public de la presse en Espagne (1781-1808), Paris, Honoré Champion, 1998 y Joan Cavaillon Giomi, «Les libraires et la diffusion de la presse à Madrid à la fin du XVIII" siècle», El Argonauta español, n 5, 2008, argonauta@mmsh.univ-aix.fr
} 
que incluso perdura hoy día con la apelación de Boletín Oficial del Estado ${ }^{3}$. Posterior al periodo que estudiamos es la segunda etapa de la Gaceta cuando pasó a ser propiedad de la Corona en 1761 . Hasta 1778 era semanal y después bisemanal. Se editaba en el formato en cuarto totalizando cuatro páginas que correspondían a un pliego. Sus tiradas llegaron a ser considerables (10 000 ejemplares) y se distribuía en toda Espańa y en América (en 1781, las tiradas destinadas a América alcanzaban un $6 \%$ del total). Impresa en la Imprenta Real, la Gaceta estuvo siempre bajo el control del rey, lo que la confería gran credibilidad. La Gaceta llevaba mucha información y de tipo muy distinto: artículos sobre temas políticos, victorias, textos reglamentarios o legislativos, etc. y al final de cada número, podía llevar uno o varios anuncios, entre los cuales figuraban anuncios de impresos. Periódico más relevante de su época, mayormente de información política, se puede también considerar como en parte un periódico de información literaria.

Fue el profesor François Lopez quien inició el análisis de los anuncios de impresos de la Gaceta copiando en fichas o en fotocopias todos los anuncios de impresos 1697 y $1807^{4}$. Extraordinario y descomunal trabajo sin el cual este estudio no hubiera podido ser. Cuando me integré a la Universidad de Burdeos, me propuso trabajar con él y empezamos a concebir un amplio proyecto de bases de datos sobre impresos del siglo XVIII, bases que ubicamos en la Maison des Pays Ibériques ${ }^{5}$. Decidimos informatizar las fichas manuscritas y las fotocopias. Esta labor está sin terminar. De momento, se han informatizado sin embargo unas 19000 fichas, es decir el $78 \%$ del total.

Después de esta breve introducción, nuestro análisis se desarrollará en tres etapas. En la primera, presentaremos los anuncios de impresos de la Gaceta, en la segunda nos centraremos en los anuncios de impresos poéticos y en la tercera propondremos una tipología de los anuncios poéticos.

\section{I.1 Los datos que proporciona la Gaceta}

Los anuncios de impresos de la Gaceta suelen proporcionar una serie de datos que son cuando menos la fecha en que se publicó el anuncio, el

3. Sara Núñez de Prado, «De la Gaceta de Madrid al Boletín oficial del Estado», Historia y Comunicación Social, Madrid, vol. 7, 2002, p. 147-160.

4. De su interés por la Gaceta es valioso testimonio su trabajo: «Las obras extranjeras anunciadas en la Gaceta de Madrid. Estudio diacrónico. Elementos de una estadística», in Estudios de Historia Social: número monográfico Periodismo e Ilustración en España, Actas del congreso de Madrid, noviembre de 1989 n 52/53, Madrid, 1991, p. 303-311.

5. Para una descripción completa de la base, ver Jean-Pierre Dedieu, «El sistema NICANTO», Bulletin hispanique, 99, n 1, 1997, p. 325-336 
título y casi siempre el nombre del autor y el lugar de venta. Sin embargo, si los primeros anuncios solían ofrecer pocos datos, conforme van pasando los años, van aumentando hasta constituir un amplio texto con elementos que hoy día llamaríamos claramente publicitarios (público destinatario, cualidades o méritos del autor, valor, estructura e interés de la obra, etc.). En la base, fue necesario establecer un modelo de ficha con tres tipos de campos: los que permitían integrar los datos que proporcionaban los anuncios, los que permitían completar los datos de la fuente (campos para el autor cuando por ejemplo en el anuncio sólo se menciona al traductor, etc.;) y los que servían para el análisis (campos de indexación o de codificación de datos como para los lugares de venta, los tipos de impresos, las materias, etc.). A veces, los anuncios proporcionan datos cualitativos de gran interés. Pueden ser datos profesionales del editor (entendido como el que se encarga de la edición y aparece en la portada como autor), del propio autor, del traductor o comentarista. Son datos profesionales (universitario, militar, médico, académico, etc.) o que precisan la calidad (noble, eclesiástico). Conforme van pasando los años, y cada vez con más frecuencia, los anuncios también indican el precio y a veces las condiciones de suscripción o las eventuales ofertas (en caso de compra de varios ejemplares, etc.). La naturaleza del impreso (libro, estampa, etc.) su formato, el número de páginas, la utilidad de la obra, si tiene láminas, los tipos de versos, etc. y la indicación del lugar de venta (en una imprenta, librería, en la portería de un convento, en las gradas de San Felipe, en casa del autor) son otros tantos elementos que pueden proporcionar los anuncios de la Gaceta.

Es necesario subrayar que la interpretación de los anuncios plantea una serie de dificultades. La simple identificación de la obra anunciada no resulta siempre fácil. En efecto, en algunos anuncios, el título viene abreviado cuando no deformado, sobre todo si es una obra en idioma extranjero. Cuando el título es completo, a veces, se trata de una obra de la cual no se conserva ningún ejemplar conocido, en bibliotecas públicas por lo menos, ni que tampoco aparece en los grandes repertorios bibliográficos. Los problemas de identificación de los autores, traductores, comentaristas o editores son muy similares debido a las posibles deformaciones de su nombre o al ser autores desconocidos. A pesar de estas dificultades, la base ofrece una primera serie de resultados que permiten esbozar algunas tendencias en cuanto a la publicidad del impreso poético en la primera mitad del siglo XVIII.

\section{I.2 La espectacular progresión de los anuncios}

Veremos primero de qué forma fueron apareciendo y luego la evolución cuantitativa de los anuncios. Los años estudiados e informatizados son los 
siguientes.

$$
\begin{aligned}
& \text { - de } 1697 \text { a } 1764 \\
& \text { - de } 1767 \text { a } 1779 \\
& \text { - el año } 1783 \\
& \text { - de } 1791 \text { a } 1794 \\
& \text { - el año } 1807 .
\end{aligned}
$$

El cuadro $\mathrm{n}^{\circ} 1$ en los documentos anexos indica el número de anuncios por año. La tendencia general es la de un aumento constante del número de anuncios como lo demuestra el cuadro siguiente.

\begin{tabular}{|l|c|}
\hline Años & Media anual de anuncios \\
\hline $1697-1726$ & 3 \\
\hline $1727-1760$ & 186 \\
\hline $1761-1783$ & 309 \\
\hline $1791-1807$ & 1301 \\
\hline
\end{tabular}

En una primera fase que concluye en el año 1726, el número de anuncios crece pero sin llegar al centenar de anuncios por ańo; la media anual se estable en 3 anuncios por año. En la segunda etapa que termina en 1760, puesto que a partir de 1761 el control de la Gaceta por la corona se vuelve más estrecho, el crecimiento es espectacular con una media anual de 186 anuncios, más de tres anuncios por ejemplar de la Gaceta. La progresión entre 1761 y 1783 (la elección de este año se debe únicamente al hecho de que faltan todavía años por informatizar) sigue siendo importante con una media anual de 309 anuncios. Pero los cinco ańos estudiados entre 1791 y 1807 arrojan unas cifras que evidencian un crecimiento de nuevo espectacular dado que la media anual alcanza los 1301 anuncios. Incluso en el año 1807, y por primera vez, el número de anuncios supera los 2000. Con una publicación ya bisemanal, son casi de media 13 anuncios por número.

Como lo había señalado François Lopez ${ }^{6}$, de ser algo ocasional y de poca relevancia, en un siglo, la publicidad del impreso en la Gaceta se ha convertido en un elemento fundamental del periódico. No es el lugar para

6. François Lopez, «El libro y su mundo», en La República de las letras en la España del siglo XVIII, Madrid, CSIC, 1995, p. 118: «Esta práctica publicitaria que tímidamente apareció a fines del siglo XVII, en 1697, fue haciéndose más frecuente en los primeros decenios del siguiente, a partir ya de 1719, llegando a ser muy abundantes y detallados dichos anuncios con la Ilustración.» 
profundizar esta evolución de la Gaceta $^{7}$, pero sin ir más allá demuestra también que el público de lectores y de compradores potenciales del impreso creció considerablemente en un siglo.

Veamos ahora la progresiva aparición de los anuncios de impresos. Ya desde el primer año la Gaceta tuvo como función publicar anuncios de impresos y la Corona fue la primera en utilizar esta posibilidad -: el primer anuncio de impreso - «Las Capitulaciones de Olanda ${ }^{8}$ - es el del 17 de diciembre de 1697; algo normal puesto que la Gaceta era el órgano oficial de la Corona. El anuncio de impreso en este caso tenía que reforzar la dimensión propagandista de la Gaceta donde los lectores podían ver todo el esplendor de la Corona, sus victorias y gloriosos tratados, etc., así como seguir la vida de los miembros de la familia real (nacimientos, bodas, enfermedades, etc.) y todos los acontecimientos importantes de la Corte (festividades, embajadas, etc.). Del miércoles 19 de abril de 1701, es el primer anuncio de un impreso de propaganda de la familia real: «La descripción del adorno, por menor, que se hizo en esta Corte a la real entrada de su Majestad...». Son anuncios de impresos de historia pero de una historia que (por lo menos en los primeros años) se limita a alabar la política internacional o militar del rey. El primer anuncio de un impreso jurídico es del año 1707 con el «Decreto que Su Magestad ha expedido tocante al Comercio de Indias».

Sin embargo, los anuncios que dominan en los primeros años son los almanaques llamados "pronósticos»: «Pronostico sobre el año del Señor» en 1697 y en 1698, el «Piscator de Sarrabal». El primer anuncio de un libro religioso es de 1698 con «La Cuaresma del padre Señeri». El año siguiente se publica el primer anuncio de historia con la «Historia de Alexandro Magno de Quinto Curcio» y la presencia de libros de anuncios de historia se va a volver constante con además de la historia antigua, la historia europea (primer anuncio en 1702 con el «Compendio anual de todos los sucesos principales, acaecidos en la Europa, el año pasado de 1701», impreso a mitad camino entre obra histórica y periódico) y la historia nacional con en 1700 la «Sinopsis Historica chronologica de España».

Si exceptuamos la «Historia Poetica, para la inteligencia de los Poetas, y Autores Antiguos / Escrita en lengua Francesa, por el... Padre Pedro Gautruche, de la Compañia de Jesus.- Aora traducida en... castellano por Don Pablo Vertejo» anunciada el 4 de abril de 1719, y que no es propiamente una obra literaria, hay que esperar el anuncio del 11 de febrero de 1721

7. Estomos preparando un libro sobre el conjunto de los anuncios de la Gaceta.

8. El 20 de septiembre de 1697 fue firmado en la ciudad de Rijswijk el tratado que ponía el punto final al enfrentamiento de Francia contra la Gran Alianza, a la Guerra de los Nueve Años. 
para que aparezca el primer anuncio de un impreso de literatura: las «Obras lyricas» de Francisco de Bances cuyo título completo es «Obras lyricas de Don Francisco Antonio de Bánces Candamo / Que saca a luz D. Julian del Rio Marin", impreso en Madrid en 1720 por Nicolás Rodríguez Francos. Por fin el primer anuncio de una obra de ciencias es el de la «Pharmacopea Triumfante de Don Félix Palacios, En la librería de Anisson, en la Calle de las Carretas» publicado en 1713.

Los almanaques, las obras de religión, de historia, de propaganda real indirecta o directa, de derecho, de literatura y de ciencias son, a partir de 1713, las materias presentes de manera casi continua aunque sí en proporciones muy distintas.

La indexación de las materias en la base de datos está sin acabar y sólo se han analizado los ańos 1697-1724 que totalizan 706 anuncios. El análisis de la repartición por materias es el siguiente:

\begin{tabular}{|c|c|c|l|l|l|c|c|}
\hline Años & Pronósticos & Historia & Religión & Ciencias & Literatura & Derecho & $\begin{array}{c}\text { Por } \\
\text { clasificar }\end{array}$ \\
\hline $1697-1704$ & 37,5 & 28,3 & 15,7 & 1,1 & 27,4 & 0,0 & 0,0 \\
\hline $1705-1709$ & 40,0 & 26,7 & 13,3 & 0,0 & 38,3 & 0,8 & 0,0 \\
\hline $1710-1714$ & 20,0 & 17,9 & 60,0 & 8,6 & 6,2 & 0,0 & 1,1 \\
\hline $1715-1719$ & 33,3 & 8,7 & 53,2 & 17,1 & 6,4 & 2,4 & 5,6 \\
\hline $1720-1724$ & 5,1 & 9,8 & 61,0 & 12,0 & 9,6 & 4,7 & 0,6 \\
\hline
\end{tabular}

Tres materias tienden a disminuir: los "pronósticos» sobre todo a partir de 1720; la historia cuya disminución es constante entre 1697 y 1715, estabilizándose entonces en un casi $10 \%$, y la literatura cuya disminución es más temprana: a partir de 1710 está por debajo del $10 \%$ de media quinquenal. Las ciencias progresan a partir de 1710 hasta superar el 10\% $\mathrm{y}$, en menor medida, también progresa el derecho a partir de $1715^{\circ}$ pero sin alcanzar el $5 \%$. No obstante, la progresión más espectacular es la de las obras de religión. Parece que la Iglesia toma conciencia de la importancia de los anuncios y a partir de la década de 1710, los anuncios de obras religiosas superan siempre más de la mitad del conjunto.

\section{I.3 La evolución cuantitativa de los anuncios poéticos entre 1697 y 1750}

El cuadro más adelante permite ver los años que se han informatizado. El vaciado ha sido completo entre 1697 y 1750 (véase el Cuadro n ${ }^{\circ} 2$ en

9. Raquel Rico Linage, «Publicación y publicidad de la Ley en el siglo XVIII: La Gaceta de Madrid y el Mercurio histórico-político", Anuario de historia del derecho español, 1987, n 57 , p. 265-338. 
los documentos anexos). En cincuenta y cuatro años, se publicaron 4679 anuncios de impresos, de los cuales 247 son anuncios de obras poéticas o en relación con la poesía, o sea el 5,28 \% del total. Sin embargo, los anuncios de 1713 a 1718 no mencionan impresos poéticos. Es sólo a partir de 1719 cuando la presencia anual de anuncios de impresos poéticos se vuele constante y regular. El porcentaje de estos anuncios aumenta de forma bastante regular como lo revela el cuadro siguiente:

\begin{tabular}{|l|l|}
\hline $1697-1725$ & 3,2 \\
\hline $1726-1730$ & 3,5 \\
\hline $1731-1735$ & 6,6 \\
\hline $1736-1740$ & 5,3 \\
\hline $1741-1745$ & 6,1 \\
\hline $1746-1750$ & 8,1 \\
\hline
\end{tabular}

El movimiento general de las medias quinquenales es el de una progresión limitada pero constante. A partir de la década 1731-35, el porcentaje de anuncios de poesía supera el $5 \%$ alcanzando su nivel más elevado en la década 1746-1750 con un 8,1\%. Sin embargo estas medias ocultan variaciones importantes. En los veintidós primeros años, sólo en dos años se anuncian impresos poéticos. A partir de 1719, su presencia anual es constante. El año 1746, con 15,2 \%, es el año con mayor porcentaje de anuncios poéticos.

\section{LoS ANUNCIOS DE IMPRESOS DE POESÍA}

Antes de estudiar estos casi 250 anuncios de impresos poéticos conviene precisar algunos elementos. Los criterios para considerar que un anuncio trata de un impreso poético han sido varios. En algunos casos, la autoría permite a veces determinar que se trata de obras de poesía ${ }^{10}$, en otros, más numerosos, el título indica que se trata de una forma poética cuando por

10. Una visión de conjunto de los autores y de las obras de poesía ofrece Alain Bègue, "Albores de un tiempo nuevo: la escritura poética de entre siglos (XVII-XVIII)» $\mathrm{y}$ "Relación de la poesía española publicada entre 1648 y 1750», en Aurora Egido, José Enrique Laplana (eds.), La luz de la razón. Literatura y Cultura del siglo XVIII. A la memoria de Ernest Lluch, Institución Fernando el Católico, 2010, respectivamente p. 37-69 y p. 399-477. Debo agradecer a Alain Bègue el amable envío de estos dos importantes trabajos donde el lector encontrará además una bibliografía al día. 
ejemplo pone «en verso» o indica una composición métrica tradicional «romance», «soneto», etc. También se han incluido las obras mixtas con partes en prosa y otras en verso, y las traducciones, transcripciones o traslados en verso de obras (religiosas por ejemplo). Por fin, las obras de teoría o las de debate sobre poesía también se han considerado como formando parte del conjunto sin ser stricto sensu obras de poesía.

Organizar, clasificar temáticamente, proponer en definitiva una tipología de los anuncios de poesía ofrece dificultades. Las formas y los temas cuando son conocidos o identificables permiten sin embargo esbozar una tipología que futuros estudios podrán matizar y completar en una por seguro necesaria revisión.

Una primera categoría podría reunir la "poesía circunstancial», es decir la producción de obras que tienen que ver con un acontecimiento peculiar relacionado con la vida de la familia real (nacimiento, boda, entrada real, victoria, etc.), con la vida religiosa (beatificación, milagro, etc.), con la naturaleza (epidemia, terremoto, cometa, plaga de langostas, etc.). Una segunda categoría es la de obras poéticas completas de un autor (Bances Candamo). Las poesías líricas, amatorias también podrían formar una categoría. La edición, comentada o no, de poetas de la Antigüedad grecolatina podrían constituir la cuarta categoría; otra la poesía religiosa así como las obras de teoría literaria y debates sobre poesía o incluso los anuncios de publicaciones periódicas donde pueden aparecer textos poéticos o teoría literaria vinculadas con las poéticas.

El volumen de anuncios rebasa los límites de este artículo y dejamos para un trabajo más amplio la explotación completa de la base. Nos ceñiremos al análisis de dos categorías, las ediciones de poetas de la Antigüedad y las poesías religiosas.

\section{II.1 La poesía greco-latina}

Antes de adentrarnos en el análisis de los anuncios de poesía greco-latina, conviene recordar el debate en torno a la traducción en prosa o en verso. En la reseña de el Diario de los literatos ${ }^{11}$-artículo VI de su tomo VI- de la obra de Suárez de Figueroa (autor que analizaremos a continuación), después de describir los doce volúmenes que componen la obra, empieza el comentario propiamente dicho con una reflexión sobre el tema de si se debe traducir en prosa o en verso a los poetas de la Antigüedad:

11. Utilizamos la edición facsímil con estudio introductorio de Jesús M. Ruiz Veintemilla, Ed. Puvill Libros, Zaragoza, 1987. 
Es punto juntamente controvertido entre los Professores de erudicón, y buenas letras, qual sea mas acertado traducir los Poemas en verso, o en prosa? Alegan los Parciales de esta, que la traducción en verso no puede ser fiel, ya por la fuerza del consonante, ya por la necesidad de las Perifrases, y Epitetos precisos para el complemento del numero de los pies, o silabas, o ya porque las vozes, y locuciones Poeticas de la lengua original no suelen lograr en la del Traductor su debida correspondencia: y finalmente, que la Prosa como mas clara, mas abundante, y mas libre, y expedita que el verso, es mas capaz que este de expresar el sentido, y concepto del Poeta.

Los Valedores de la Poesia defienden al contrario, que la Prosa, por buena que sea, no puede menos de robar a la Poesia mucha parte de su fuerza, gracia, y primor: que el cuerpo de un Poema destituido de la harmonia, viveza, y alma Poética, no es cuerpo, sino cadáver y por consiguiente, que las traducciones de verso en prosa, que algunos llaman fieles, no se deben reputar sino por muy infieles, encontrándose el Autor que en ellas se busca, tan desfigurado, que aun los que mas le han tratado, no lo conocen.

Sigue estableciendo el artículo una lista de autores españoles traductores de poetas griegos o latinos y concluye que «estos, y otros Autores no llevaron otro fin, mas que el de facilitar la inteligencia de los Poetas, y ayudar la rudeza de los principiantes».

Los 12 anuncios de poesía latina se reparten cronológicamente como sigue:

\begin{tabular}{|c|c|l|l|}
\hline Años & $\mathrm{N}^{\circ}$ de anuncios & \multicolumn{2}{|c|}{ Autores } \\
\hline 1727 & 2 & Ovidio & \\
\hline 1371 & 1 & Horacio & \\
\hline 1733 & 1 & Fedro & \\
\hline 1735 & 1 & Ovidio & \\
\hline 1736 & 1 & Ovidio & \\
\hline 1737 & 2 & Ovidio & \\
\hline 1738 & 2 & Ovidio & Esopo (1) \\
\hline 1739 & 2 & Virgilio/Ovidio (2) & \\
\hline
\end{tabular}

Los anuncios de ediciones de autores de la Antigüedad se concentran en los años1727-1739, reuniendo a un poeta griego, Esopo, y a cuatro romanos -Ovidio, Fedro, Horacio y Virgilio.

Domina ampliamente Ovidio con nueve anuncios de los cuales ocho corresponden a ediciones de sus obras por Ignacio Suárez de Figueroa: 
«Obras de Ovidio traduzidas y comentadas en castellano por Diego Suarez de Figueroa", Madrid, 1728-1738, $4^{\circ}, 12$ vol. La distribución temporal de los anuncios corresponde a la progresiva salida de los doce tomos que no se publicaron en una sola vez. Las portadas de la obra proporcionan algunos datos interesantes. La de 1727 reza: «Comento de P. Ovidio Nason a los libros de Tristes y Ponto Por Publio Ovidio Nasón/ su autor Don Ignacio Suarez de Figueroa, Alferez de Navío/Sacalo a luz el Doctor Don Diego Suarez de Figueroa, su Tío, Calificador del Santo Oficio, Theniente de Limosnero Mayor de S. Magestad y su Capellan de Honor/Uno y Otro lo dedican al Ementissimo Señor Cardenal de Borja, Patriarca de las Indias, Etc./En Madrid: Por Francisco del Hierro». El autor fue oficial de marina y seguramente extremeño (la edición de 1733 lleva la dedicatoria siguiente: "Quien le dedica a la Muy Noble y Leal Ciudad de Badajoz»). En cuanto a su tío, miembro de la Real Academia Española de la Lengua cuyo sillón L ocupó entre 1728 y 1743, fue comentarista de las obras de José de Valdivieso ${ }^{12}$. Se trata de una traducción con comentarios que en sus Obras completas, epistolario y bibliografía, Menéndez Pelayo ${ }^{13}$, valoró en términos bastante críticos. En su análisis de la obra, cita las censuras y aprobaciones de la obra. La del «Dr. D. Juan de Serres, Presbytero, del Oratorio de la Congregación de Francia, y Administrador del Real Hospital de los Franceses de esta Corte», fechada del 7 de Junio de 1726, aclara cual era el público destinatario y el contenido de la obra:

Haviéndole examinado con toda atención que merece una obra, que ha de ser de grande aliuio, no sólo para los que empiezan a estudiar la lengua latina, sino también para los Maestros de Gramática, debo decir que es esta traducción literal tan arreglada al arte de la construcción que por ella se entenderán claramente algunos versos, cuya inteligencia ha embarazado no poco aun a los que cada día tienen por su professión estos libros en las manos, por cuya razón le debemos al Autor muchas gracias los que leemos no por sólo leer, sino es para entender lo que leemos. También se las debemos por el cuidado y trabajo que ha tenido en corregir las erratas, que en estas obras de Ovidio havian introducido la ignorancia o descuido de los Impressores, defecto que asimismo se experimenta en todos los libros, assí Latinos como Espańoles, que los Maestros de Gramática ponen en manos

12. José de Valdivieso (1565-1638), «Vida, excelencias y muerte del Gloriosísimo Patriarca San Joseph escribiola [...] José de Valdivieso [...]; coméntala [...] Diego Suárez de Figueroa [...]", Madrid, Francisco del Hierro, 1727-1728, 5 vols., citado por Alain Bègue, op. cit., p. $467-468$.

13. La edición consultada de las Obras completas, epistolario y bibliografía de Don Marcelino es la de la Biblioteca virtual Cervantes. 
de sus discípulos; y assí debemos desear que el Autor se dedique a corregir y explicar de la misma manera las obras de Cicerón, Virgilio, Valerio Máximo, fábulas de Hisopo, etc. etc., y respecto de ser, como lo es, en efecto, este comento tan útil a los aficionados a la inteligencia de la lengua latina, y haver el Autor castigado en la traducción algunas cosas que son algo duras en el original latino, soy de sentir que se le puede dar la licencia que para imprimirle solicita.

Obra para estudiantes y preceptores de gramática latina que corregía los errores de las ediciones anteriores, mas a la vez obra que censuraba («haver el Autor castigado...original latino»). El Prólogo explicita el método seguido por el autor y las condiciones de la redacción de la obra:

O Benévolo Lector, haviendo comprehendido, quando joven, con bastante propiedad la latinidad y estrańado el que entre tantos Poetas como se han traducido en nuestro idioma, huvieran dexado a Ovidio Nasón, cuya inteligencia era tan útil, por leerse en todos los generales, [...] como por ser fuente de la Rhetorica, de la erudición, y de la Poesía; tan dulce en sus quexas, como utilissimo por sus sentencias, y por sus desengaños; me pareció emprehender su Comento, lo que conseguí con no poco trabajo, por lo obscuro de muchos lugares [...]. En la explicación sólo me pareció poner lo que bastaba para la inteligencia del Poeta, citando donde podrá hallarse con más extensión. No lo apoyo con variedad de versos de nuestros Poetas Españoles, porque ellos fueron los que a él le imitaron.[...] Entre las tareas que he tenido de Matemáticas en las Academias de Marina, entre los bullicios de los Exércitos, y entre las inquietudes de los mares, he procurado imitar a Ovidio, haciendo un Metamorphoseos en su comento, del Latín Español; diversión de sus penas; alegrías de su llanto; y de su estudio amigable retiro...

Sin embargo, la valoración de Menéndez Pelayo dista mucho de la del autor y de su censor:

La traducción es groseramente literal, al modo de las que ahora llaman interlineales, y que sólo pueden ser útiles para los principiantes más rudos, si bien con el grave inconveniente de apartarlos del manejo del diccionario, sin el cual es imposible adquirir dominio de una lengua muerta. Estas versiones llamadas en Espańa remedia-vagos fueron una de las principales causas de la decadencia de los estudios clásicos, y continúan siéndolo para muchos literatos españoles. (¡proh pudor!) que leen los poetas clásicos en traducciones en prosa francesa, todavía más infieles y más ridículas que las de nuestros antiguos dómines. Luego dicen que han leído el texto con una interlineal. ¡Buen interlíneas nos dé Dios! Para leerle de tal manera, es mejor no leerle de ninguna, o resignarse a aprender los rudimentos de la gramática latina. [...] 
El Comento de Suárez de Figueroa es indigesto, y de erudición proletaria, bebida en cualquiera Poliantea y amplificada con lección tumultuaria de poetas latinos y españoles.

En la ya mentada reseña de el Diario de los literatos, también se mencionan los errores de traducción de Suárez de Figueroa clasificándolos en cuatro clases: "I - Traducciones defectuosas por demasiado literales», «II - Traducciones erradas por haverse interpretado los vocablos, según su mas obvia, y vulgar significación, o por la aparente analogía que tienen con otros», "III - Traducciones equivocadas por la alusión de algunas voces latinas con las Castellanas, o con otras Latinas» y «IV - Traducciones erradas puramente por falta de inteligencia del texto». ¡El total de los errores ocupa casi veinte páginas!

En diciembre de 1739, la Gaceta informó los estudiantes y maestros que ya disponían de otra edición de las obras de Ovidio junto con las de Virgilio, el «Publii Virgilii Maronis y Publio Ovidio Nafonis, que sirven para los Gramaticos, corregidos de todos los errores; que habian padecido, asi de Imprenta como de Ortografia, y restablecidos por los mejores originales Estrangeros» de don Juan González de Dios, "Cathedratico de Prima de Rethorica en la Universidad de Salamanca» ${ }^{14}$ que se hallaba en "la Librería de José de Cueńas, Plazuela de los Herradores y en Salamanca en la de Bernardo de Cueñas».

El anuncio de las obras de Fedro es de 1733. La traducción se debe al Doctor Don Juan de Serres, "Sacerdote del Oratorio de la Congregación de Francia, y administrador del Real Hospital San Luis de los Franceses de esta Corte» y se titula «Fabulas Latinas de Phedro, con notas, y traducción en Castellano / ... Con privilegio (dat. 1632) en Madrid: en la imprenta de Don Gabriel del Barrio, impressor de la Real capella de Su May. se hallara en casa de Juan de Buytrago. ia. (pagg. 255)» ${ }^{15}$. Menéndez Pelayo comentó también la edición de las obras de Horacio cuyo anuncio es de 1731. Así comenta el «Q. Horatii Flacci Carmina expurgata et accuratis notis illustrata auctore Josepho Juvancy [Joseph de Jouvancy, 1643-1719, poeta, filólogo e historiador francés] Societatis Jesu Sacerdote» impreso en Sevilla, en 1729, por López de Haro:

14. Sobre el autor, véase los artículos de José Luis Valls Toimil, «Juan González de Dios, maestro de Torres Villaroel y Catedrático de la Universidad de Salamanca», Revista de estudios, Salamanca, 1995, n 35-36, p. 123-148 y "Más sobre Juan González de Dios», Revista de estudios, Salamanca, 1997, n 39, p. 221-236.

15. Los datos provienen de Johann Gottlob Samuel Schwabe, Fabularum Aesoparum libri $V$-Phaedrus, Brunswick, 1806, p. 589. 
El texto de esta edición escolar es el mutilado del P. Jouvancy, que no sólo suprimió odas enteras y muchos pasajes de otras, sino que por escrúpulos de moralidad, que en algunos casos llegan a ser tontos y pueriles, sustituyó versos de Horacio enteramente inofensivos, con otros de su cosecha, que le parecieron más honestos. Baste, por muchos, un ejemplo. Donde Horacio escribió sin ofender los castos oídos de nadie:

Dulce ridentem Lalagem amabo,

Dulce loquentem...

el buen Padre, que no quería, sin duda, que los jóvenes oyesen hablar de la dulce risa ni del dulce hablar de ninguna Lálage, corrigió intrépidamente:

Sola me virtus dabit usque tutum,

Sola beatum.

¡Así remendaban a los clásicos los jesuítas franceses, puesto que de los nuestros no sé que cayesen nunca en semejante desvarío!

En realidad la edición anunciada en la Gaceta es la de 1731 también identificada por don Marcelino: «Reimpresión a plana renglón del Horacio expurgado, que había salido de las prensas de Sevilla en 1729».

En 1738, se anuncian las «Fábulas y vida de Isopo, con la de otros autores, traducidas por su orden nuevamente del latín en Castellano ... con el aumento de la perla de las dos Lenguas, Latina, y Espanola, etc.» Por «Juan de Lama, natural de la villa de Villablino, Montañas de Leon, se hallan en la Imprenta de Antonio Sanz, calle de la Paz»: son la primera traducción al español de Esopo ${ }^{16}$.

Los anuncios no mencionan ninguna obra de Catulo, Tibulo o Propercio, para citar a algunos de los poetas latinos más importantes. Pero al buscar traducciones de estas obras en la edición española del siglo XVIII, parece que no las hay. Todas las obras anunciadas en la Gaceta se mencionan en la Bibliografía de autores españoles del siglo XVIII de Francisco Aguilar Piñal ${ }^{17}$. La única no anunciada es "Ariadna a Theseo. Epistola decima de Ovidio/ Traducida del idioma latino al castellano por Don Esteban Antonio Pietre» y Malcampo impresa en Madrid en 1732. Con las obras de los poetas griegos ocurre lo mismo. Si no se anuncian en la Gaceta es porque no se traducen ni publican. Las primeras ediciones de Anacreonte, Píndaro o Teócrito son de la última década del siglo XVIII. En definitiva, las obras greco-latinas que se publican en esta primera mitad del siglo son más bien obras expurgadas para uso de escolares y maestros que ediciones para lectores cultos.

16. Santiago Talavera Cuesta, La fábula esópica en España en el siglo XVIII, Cuenca, Ediciones de la Universidad de Castilla-La Mancha, 2007, p. 588.

17. Francisco Aguilar Piñal, Bibliografía de autores españoles del siglo XVIII, Madrid, Consejo Superior de Investigaciones. Cientificas, Instituto «Miguel de Cervantes», 10 tomos, 1981-2002. 


\section{II.2 Los anuncios de poesías religiosas}

Los casi setenta anuncios de poesía religiosa ofrecen varios tipos. La cuarta parte de ellos son poesías hagiográficas. Los poemas que tratan de un acontecimiento local («Colocacion del Cuerpo de S. Juan de Mata, en la Iglesia de los Trinitarios Descalços», «Sagrada Metrica Lid, Certamen y Sermones en las Fiestas de Santa Maria de Jesus de Alcalá», etc.), pero que muchas veces tienen que ver con la hagiografía, superan el $10 \%$. Las obras marianas ( 4 anuncios) y las de la Pasión de Cristo ( 9 anuncios) totalizan un $17 \%$. Con menos del $5 \%$, las obras sobre la Biblia o las traducciones del Misal romano no son muy importantes. Las «Obras» completas de poetas como Pérez de Montoro o Hurtado de Mendoza tampoco llegan al $5 \%$. La categoría con mayor representación -algo más de la tercera parte- es la que podríamos llamar religiosidad, con anuncios de obras de devoción o de obras útiles en el cumplimiento de los deberes del cristiano (calendario litúrgico, etc.).

\section{II.2.1 Poesía hagiográfica}

Cualquier clasificación es imperfecta por su carácter arbitrario y porque una misma obra puede pertenecer a dos, o más, categorías. Entre las obras clasificadas como hagiografía, incluimos obras que no son vidas de santos en el sentido estricto de la palabra sino obras que se vinculan con los cultos locales y acontecimientos peculiares. Para ordenar esta amplia categoría analizaremos primero las vidas de santos que no hemos podido relacionar con un acontecimiento particular. Forman parte de este río constante de publicaciones hagiográficas que alimenta el amplio mar de la religiosidad popular. En segundo lugar, estudiaremos las obras que tienen por objeto santuarios, romerías o cultos locales. Por fin, presentaremos los impresos que tratan de las canonizaciones o traslados de cuerpos de santos.

\section{II.2.1.1 Las Vidas de santos}

El primer anuncio de vida de santo del año 1722 es la: «Vida de Santa Teresa de Jesus, en verso heroico» por el Padre jesuita Joseph Antonio Butrón y Mujica, obra dedicada al Conde Arcos e impresa en 1722, en Madrid, por Francisco del Hierro. Santa Teresa, junta con San Francisco Javier vuelve a ser el tema de la obra anunciada en 1737: "Las Hazanosas Vidas de Santa Theresa de Jesus y de San Francisco Javier en Verso, por Don Joseph Villarroel» es un impreso de 1736 cuyo título completo es "¡Ahí es una niñería! que 
de las hazañosas vidas de Santa Theresa de Jesus y de San Francisco Javier se vino a los ojos de Don Josef de Villarroel, y sale a vistas al espejo del escudo del Exmo. Conde de Gálvez» impresa en Salamanca. Carlos Mata Induráin que estudia tres vidas de San Francisco Javier valora la obra: «Las tres [vidas] presentan características diferentes, siendo la más interesante, lo adelanto ya, la de mayor elaboración artístico-literaria, la obra dieciochesca, que presenta la peculiaridad de estar escrita en versos jocoserios» ${ }^{18}$. El texto del franciscano de la observancia José de Villarroel fue apadrinado por Torres Villarroel, que redactó la censura de 1736 y además ensalzó la calidad poética de «su amigo José Villarroel» en Pascuas y aguinaldo $(1740)^{19}$. En 1755, José Villarroel publicó otra obra en verso dedicada al culto marial y en defensa de la virginidad de María: «A la Inmaculada Concepción de la Virgen María Señora Nuestra: romance, que se escribió y dedicó ... su amante,... José Villarroel, (O.F.M.)» ${ }^{20}$.

En 1727, el jerónimo Fr. Francisco de Lara publica «El sol máximo de la Iglesia S. Geronymo: Poema heroyco en octavas rithmas / sv avtor el M.R.P. Fr. Francisco de Lara» ${ }^{21}$, obra sobre el doctor de la Iglesia Latina. Según indica la portada del libro, parece que Fray Francisco de Lara fue «Predicador de Corte de su monasterio de San Isidro del Campo, extramuros de esta ciudad de Sevilla, Prior, que ha sido, de dicho monasterio, y en él, Señor de lo espiritual y temporal de la villa de Santiponze, Sevilla la Vieja, y sus términos (nullius Diocesis)».

El anuncio siguiente, de 1734, es de un autor sin identificar: Fr. Jorge Santa Rosa de Viterbo. Su «Poema Encomiastico al Venerable Doctor Subtil, y Mariano Fr. Juan Duns Scoto» estaba a la venta en la «casa de Juan Gomez, Calle Mayor». Podría ser una imitación de "Poema encomiastico a... Fray Juan Duns Escoto» del P. Fr. Joseph Ordóńez publicada en Murcia en 1733 por Joseph Díaz Cayuelas (obrita de 72 páginas en $4^{\circ}$ ).

En un «libro nuevo» según reza el anuncio de 1735 «don Manuel Montanes y Monte Alegre» reúne unas «Poesias Lyricas» cuya portada indica que van «dedicadas à la Gloriosa Virgen, y Mártyr Santa Bárbara». Después

18. Carlos Mata Induráin, «Tres vidas en verso de San Francisco Javier: Matías Vivero (1620), Francisco de Lancina (1682) y José de Villarroel (1636)», en Ignacio Arellano, Delio Mendonça (eds.), Misión y aventura: San Francisco Javier, sol en Oriente, Iberoamericana, Madrid, 2008, p. 198.

19. Carlos Mata Induráin, op. cit., p. 211.

20. El texto se puede consultar en la Biblioteca Digital de Castilla y León, Valladolid: Junta de Castilla y León. Consejería de Cultura y Turismo. Dirección General de Promociones e Instituciones Culturales, 2009-2010.

21. Publicado en Sevilla, Francisco Sánchez Reciente, 1726, 34 h., 424 p., 2 h.; 4º, Port ${ }^{\mathrm{a}}$ orl $^{\text {a }}$; cabeceras y pias grabs. 
de un largo «Soliloquio» romanzado, el autor ofrece varias poesías para cantar «Letra para cantar en la Assumpcion de nuestra Señora» (p. 28) o "Letra que se cantó en la Profession de la señora Sor Teresa de Jesus Maria, Religiosa Mercedaria». Estos textos son pruebas y ejemplos de la tradicional asociación poesía/letra/música tan importante en la práctica social de la poesía. El análisis del texto revela que se suceden formas poéticas muy variadas como rezan los títulos: «romance», «romance en paronomasias», «romance rustico para cantar por el fandango, se escribe como lo pronuncian los Andaluces», «lyra», "canción real», "quintillas», «seguidillas», «redondillas», "décimas», "sonetos», "glosas a quintillas», "glosas a quartillas", "sonetos con pies forzados» y unos "versos macarrónicos» titulados «Cataplasma en mal latin, que sana en buen romance».

Este ejemplo es una prueba más de lo analizado por Antonio Alatorre: «Pero hacia 1650, se le ocurrió a alguien sacar a los [versos] esdrújulos del ámbito áulico y académico y exhibírselos a la gente común y corriente como objetos curiosos y llamativos [...] La gente se aficionó al juego, y los poetas ultrabarrocos, sobre todo el muy aplaudido León Marchante, se esmeraron en darle gusto. Los romances esdrújulos son especialmente frecuentes en los villancicos religiosos» ${ }^{22}$.

En el año 1736, se publica la «Vida y milagros de el thaumaturgo español, Moyses segundo, redemptor de cautivos, abogado de los felices partos, Sto Domingo Manso, abad benedictino, reparador de el Real Monasterio de Silos / que dedica, y ofrece ... Fr. Sebastian de Vergara». El título mencionado en la Gaceta difiere ligeramente-«Vida de Santo Domingo de Silos, en que se dan a luz con sus mismas vozes los Originales antiguos, assi Latinos como Castellanos, en prosa y en verso"- y parece indicar que se trata en realidad de una edición de la Vida de santo Domingo de Silos de Berceo, la que utilizó Frida Weber de Kurlat en su estudio "La "visión" de Santo Domingo de Silos. Berceo "Vida de Santo Domingo de Silos"”, cuartetas 224-251»"23.

De Luis Antonio de Oviedo Herrera y Rueda, Conde de la Granja (Madrid, 1636 - Lima, 1717), poeta y dramaturgo, partícipe de la Academia de Palacio de Lima, la Gaceta anuncia en 1739 la venta en la «Librería de José Pimentel, calle de las Carretas» de su famosa Vida de Santa Rosa de Lima. La primera edición de la obra se publicó en Madrid en 1711 y hubo una reedición en México en 1729. No hemos encontrado edición más cercana a la fecha del anuncio.

22. Antonio Alatorre, Cuatro ensayos sobre arte poética, México, El Colegio de México. Centro de Estudios lingüísticos y literarios, 2007, Serie Trabajos Reunidos, 3, p. 73-75.

23. Estudios ofrecidos a Emilio Alarcos Llorach: (con motivo de sus XXV años de docencia en la Universidad de Oviedo), Oviedo, Universidad de Oviedo, 1979, p. 489-508. 
«El Sol de los Anacoretas, Vida de San Antonio Abad, Poema en Octavas» de Pedro Nolasco de Ozejo cuyo anuncio se publicó en 1737 forma parte de las obras reseñadas en el Diario de los literatos.

El artículo XVI del tomo IV publicado en 1738 es una dura crítica de la obra. El texto revela un enfrentamiento entre los «Diaristas» y Pedro Nolasco de Ozejo. A raíz de que "habían censurado [los Diaristas] con injusticia su Poema de San Antonio», Ozejo había publicado el 13 de enero de 1738 «un papel en octavo, con 36 paginas y media, y tres hojas de principios» titulado «Los Impressores, y Plumistas de la Corte, en busca del Diario Apologetico de las murmuraciones...». Los Diaristas le contestaron duramente «notarèmos por mayor los defectos, y monstruosidades que se hallan en èl, à modo de sabandijas, engendradas del excesivo calor, y humedad de un numen Poetico, que es el agente principal de esta corrupción». Revela el artículo que Ozejo siguió «la vida que escrivo Cevallos» y que en los cinco cantos que la componen, «No se reconoce en toda la obra parte alguna, que le merezca al arte el mas minimo precepto. La erudición, sobre ser vulgar, es tan escasa, que apenas se percibe [...]. No parece sino que arranco tal qual texto de la Santa Biblia para apedrear a los Lectores, confundiéndolo con el ripio que recogio en los caramanchonos del Theatro de los Dioses». Falto de erudición, pero también pecando en la acumulación de neologismos: «no debemos olvidar la muchedumbre de vozes, unas estrañas, y otras ridículas, que introduce en nuestro Castellano sin más razón que la de aumentar el erario de los Poetas silvestres, y crecer el diccionaro de cultilatinigerigonza: [ ...] materia comburiente [...] Lagrimar aljofares [...]». En cuanto a la calidad de sus versos, el Diario sigue en la misma línea de una feroz crítica: "Aunque los versos fueran excelentes, no podían dexar de ser imperfectos, a causa de los malos pies que tienen algunos, que padecen callos, juanetes, sabañones, y los demás accidentes, que se originan de la superfluidad. Fuera muy largo el dar razón de todos los que pecan por sylabas de mas, y por mala colocación de los acentos [...] Hai assisismo infinitos versos que por mala expresion, ridiculez de las metáforas, frialdad de los pensamientos y elección de consonantes, son indignos de un Poema tan serio, como el de la vida de un Santo». La portada del ejemplar que se conserva en la Biblioteca Nacional ofrece un ejemplo del estilo de Ozejo «El Sol de los Anacoretas, la Luz de Egipto, el Pasmo de la Tebaida, el Assombro del Mundo, el Portento de la Gracia». La Gaceta publicó un segundo anuncio de la obra en 1738.

\section{II.2.1.2 Santuarios y cultos locales}

En 1729, se anuncia la obra de Antonio Rioboo y Seijas (1685-1763): «Nuestra Señora de la Barca». Natural de Allo, municipio de Corcubión 
(La Coruña), antiguo colegial de San Jerónimo, canónigo de la Catedral de Santiago de Compostela, predicador y autor de numerosas obras históricas y literarias. Antonio Rioboo figura también en la lista de «autores aludidos» de la "Copia del informe de los revisores de la Real Academia de la Historia sobre la presentación, título y examen de las obras de Luis José Velázquez» : era miembro honorario de la Real Academia de la Historia que conserva varios documentos suyos. La obra trata del célebre santuario de Nuestra Señora de la Barca en la localidad gallega de Muxía, en la denominada Costa de la Muerte, donde cada año el 8 de septiembre se hace una romería muy concurrida para celebrar la aparición de la Virgen que llegó en una barca para animar al apóstol Santiago, que se desesperaba porque no conseguía convertir à los vecinos. A propósito de este impreso. Ofelia Rey Castelao ${ }^{24}$ indica: "en 1728 se imprime en Santiago La Barca más prodigiosa, poema historial sobre el santuario de la Virgen de la Barca ofrecido «al culto theatro de los doctos y alumnos de las Musas para incentivo de la devoción»; después de un romance dedicado por D. Antonio Cernadas y Castro, cura de Fruime, al autor, prosiguen este poema y un tratado sobre la tradición de la aparición de la Virgen al Apóstol Santiago en el puerto de Muxía «sin pretenderle más asenso que el que dicta la fee humana». En su Teatro crítico, Feijoo alude al santuario:

Pocos años ha que en la Ciudad de Santiago fe hizo información plena de que en el Santuario de Nuestra Señora de la Barca (ázia el Cabo de Finis Terræ) fe veian frequentemente Angeles danzando delante de aquella Santa Imagen. No solo Angeles, mas toda la Corte Celestial, según las deposiciones de muchos, baxaba á dar culto al venerable Simulacro. Uno veía á San Francisco con sus llagas; otro á Santa Catalina con fu rueda; otro al Apóstol Santiago con fu esclavina. Otro un Ecce-homo; otro un Crucifixo. Cada uno veía el Santo, o Mysterio que quería; y solo falto que alguno viesse las once mil Vírgenes, y las contasse una por una. A todo esto dio ocasión una cortina pendiente delante de la Imagen, la qual, quando, por estar descosidos por una parte la tela, y el aforro, el ambiente movido, introduciendofe por la abertura, la agitaba, juntándose la circunstancia, de que el Sol hiriesse una vidriera puesta enfrente, con los varios ondeos de la tela, y el aforro, hacia diferentes vifos; que cada uno interpretaba á fu modo. El portento corrió por toda España, acreditado por aquella información. Pero no fe tardó mucho en

24. Ofelia Rey Castelao, "Producción impresa y promoción eclesiástica en la Galicia de fines del Antiguo Régimen", Semata, Ciencias Socias e Humanidades, Universidad de Santiago de Compostela, 1998, vol. 10, Cultura, poder y mecenazgo, p. 281-319. La cita está en la p. 290. 
hacer nuevo, y, mas atento examen por fugetos de gran juicio, y literaturas que no fe halló, sino una imperfectissima apariencia ni aun esta perseveraba, quando en lugar de aquella cortina fe ponía otra.

En su amplio teatro - con en el antiguo significado de panorama- de críticas de las supersticiones, supuestos milagros y falsa creencias religiosas, Feijoo denuncia aquí la fraudulenta burla milagrera que aprovecha la fama del santuario.

Los santuarios madrileños tienen buena representación en los anuncios. En 1737, se anuncia «La segunda impresión de la Historia Poema de La Virgen de la Almudena y Milagros de San Isidro» de Lope de Vega. La Virgen de la en aquel entonces parroquia de la Almudena, había sido ya fuente de inspiración de varias obras áureas, las de Juan de Vera Tassis, Jerónimo de Quintana y Calderón de la Barca. En cuanto a Lope en su libro de poemas Triunfos divinos figuraban unas octavas dedicadas a la Virgen de la Almudena. La obra -publicada en 1625 y dedicada a la condesa de Olivares es una versión a lo divino de los Triomphi de Petrarca- se termina con los tres cantos de La Virgen de la Almudena, largo poema de 904 versos dirigido a la reina Isabel de Borbón. En 1599, el mismo año en que, como secretario del marqués de Malpica, acompañó al rey Felipe III y a Margarita de Austria con motivo de sus bodas celebradas en Valencia, Lope de Vega publicó su poema San Isidro. Los dos temas también dieron lugar a dos comedias suyas: La beatificación de san Isidro y La Virgen de la Almudena. Notemos que parece que la gran popularidad de que gozaban los dos santos patronos de Madrid, motivó esta publicación conjunta de los dos poemas extraídos de los Triunfos divinos.

La otra patrona de Madrid, la Virgen de Atocha, también fue durante todo el Siglo de Oro tema de libros, poesías y comedias. En 1750, se vuelve a editar «La Patrona de Madrid restituida, Poema Heroyco à Nuestra Señora de Atocha ...en lengua antigua...por el ingenioso Salas Barbadillo» cuya primera edición fecha de 1609. El Journal des Savants, en su número de noviembre de 1751, da una reseña de la obra en la cual niega la dimensión heroica del poema:

La Patrona de Madrid, \&c. La Patrone de Madrid, Poëme Héroïque à Notre-Dame d'Atocha, par Alfonse Salas Barbadillo. Seconde Édition augmentée. Madrid, chez Manuel Ignace de Pinto, 1750, in 8. L'ouvrage est bon, quoiqu'il ne soutienne pas le titre de Poème Héroïque; l'Auteur a du génie, \& occupe une des premières places fur le Parnasse Espagnol.

En el año 1736, el P.M.Fr. Buenaventura Terrín, del orden de Trinitarios Descalzos publica «San Rafael Custodio de Córdoba, Poema Heroyco». 
Santo de grande, tradicional y muy antigua devoción en Córdoba, por su milagrosa intervención durante la epidemia de peste que asoló España diezmando la población a finales del siglo XVI. Cuenta Teodomiro Ramírez de Arellano y Gutiérrez en sus Paseos por Córdoba: o sean apuntes para su historia (Córdoba, 1873-1875, Imp. de Rafael Arroyo, 3 v, $21 \mathrm{~cm}$ ) que el Arcángel apareció cinco veces al P. Roelas y que en la quinta aparición le dijo: «Yo te juro, por Jesucristo Crucificado, que soy Rafael, ángel a quien Dios tiene puesto por guarda de esta ciudad». Quizás la obra del P. Terrín esté relacionada con el final en 1732 de las obras de la iglesia dedicada a su culto, la Iglesia del Juramento de San Rafael, o de la consagración y bendición del templo que tuvo lugar el 25 de agosto de $1735^{24}$.

Sin que se trate exactamente de una obra relacionada con el culto local de santos o vírgenes, incluimos en este apartado otra reedición de un autor áureo: el «Discurso metrico-ascetico sobre la inscripcion "Psalle, et Sile", que está gravada en la verja del choro de la Santa Iglesia de Toledo, Primada de las Espańas / Obra que compuso el superior numen del eruditissimo Don Pedro Calderón de la Barca, Cavallero del Orden de Santiago / Sacale a luz Don Antonio Fernandez de Azevedo» cuyo anuncio es de 1744. La obra impresa en Madrid por Lorenzo Francisco Mojados en 1741 es muy corta: 8 h. y 16 p. en $8^{\circ}$ de papel marquilla. El poema fue redactado por Calderón de la Barca cuando en 1653 residió en Toledo como racionero de la catedral y publicado en Madrid con el título de «Exortación panegírica al silencio. Motivada de su apóstrophe Psalle, et sile. A la protección del Eminentísimo Reverendissimo Señor Don Baltasar de Moscoso y Sandoval, Cardenal Presbytero de la Santa Iglesia de Roma, del Título de Santa Cruz en Ierusalen, del Consejo de Estado de su Majestad, Arçobispo de Toledo, Primado de las Españas y Gran Chanciller Mayor de Castilla, \&c. Por Don Pedro Calderón de la Barca, Cauallero de la Orden de Santiago y Capellán de su Majestad en su Real Capilla de los Señores Reyes Nuevos». Se publica en 1662 con aprobación en Toledo del 21 de diciembre de 1661 y con un grabado de Pedro de Villafranca. La divisa Psalle et Sile - "Canta y calla»está situada en la verja del coro de la iglesia de los Reyes Nuevos de Toledo.

\section{II.2.1.3 Canonizaciones y traslados de reliquias}

Hay tres anuncios de obras relacionadas con procesos de canonización de santos. La primera es, en 1730, la «Obsequiosa metrica expression, breve

25. José María Torres Pérez, «La iglesia del Juramento de San Rafael en Córdoba (17961806)», Norba-arte, $\mathrm{n}^{\circ} 7,1987$, p. 195-222. 
Epitome de la vida de San Cayetano». Su autor, Gabriel de Artave y Anguita, cruzó el Atlántico en 1735, rumbo a Valladolid (México) de cuya catedral fue canónigo racionero además de ser familiar del Santo Oficio. Puede que leyese el «Epitome de la vida del glorioso S. Cayetano Tiene fundador de los Clerigos Reglares / escrito por el P. Don Manuel Calascibetta, religioso de la misma Orden Impresso en Madrid por Pablo de Val, año de 1653 y aora nuevamente en Mexico: por los Herederos de la Viuda de Bernardo Calderon, 1691». La relativa recién canonización de San Cayetano (en 1671) desencadenó una serie de obras literarias: «Vida, y muerte de San Cayetano / de seis Ingenios desta Corte» (1672), el Epitome de Manuel Calascibetta (1691), la «Vida, virtudes y milagros del glorioso patriarca San Cayetano de Thiene, fundador de los Clérigos regulares» de Eugnio Pedro Calderón de la Barca (Madrid: Impta. Rl., 1723, [8], 448 [i.e. 440] p.; 4o $)^{26}$, y «El iris eucharistico, que en señal de la Divina Providencia, publica en el santo de la Providencia Divina, la Gloria de todos los Santos en la semejança de sus virtudes: sermon del señor san Cayetano Thiene fundador de los PP. Clerigos Reglares de la Divina Providencia ...: patente el Santissimo Sacramento por Quarenta Horas, con la circunstancia de salud recobrada, invocada su intercession / predicole Fr. Nicolas Joseph de Mallorca religioso de los Menores Capuchinos ... Año 1728; sacalo à luz un devoto cordial, y fino de el santo Nicolás José de Mallorca (O.F.M. Cap.)» (Palma, por Pedro Capò Imp., 1730, 23 p.; 4º). Asimismo de la popularidad del santo hablan los numerosos grabados y estampas que se editaron en el siglo XVIII.

En 1738, se anuncia una obra titulada «La Elocuencia del Silencio» de «Miguel de Reina Zevallos, abogado de los reales Consejos, y de la Audiencia de Mexico». El título completo indica el tenor hagiográfico de la obra: LA ELOCUENCIA del silencio: poema heroico, vida y martirio del gran protomártir del sacramental sigilo, S. Juan Nepomuceno». Impresa en Madrid en 1738, la obra se publica pocos años después de la controvertida canonización del santo a la cual se oponían los jesuitas. Beatificado el 31 de mayo de 1721 y canonizado por el papa Benedicto XIII el 19 de marzo de 1729, su figura se popularizó -patrón del Cuerpo de Infantería de Marina de España en 1758como la del primer mártir por defender el voto del secreto de confesión.

26. El Padre Eugenio Calderón de la Barca es el autor de la obra según Francisco Aguilar Piñal, op. cit., tomo II, $\mathrm{n}^{\circ}$ 00564. En el «Índice general / alfabético / de todos los títulos / de comedia, / que se han escrito / por varios autores, / antiguos, y modernos / y / de los autos sacramentales / y alegoricos, / assi de Don Pedro Calderón: de la Barca, / como de otros autores / clásicos. Este índice, y todas las comedias», impreso en Madrid, en 1735, por Alfonfo de Mora, se menciona una «Vida, y muerte de San Cayetano (p. 120) sin que se indique el nombre de su autor. 
La tercera obra es la «Descripción métrica-lacónica de las plausibles fiestas que ejecutaron los Padres de la Sagrada Religión de la Compañía de Jesús en la Canonización de San Juan Francisco Regis» por Gómez Arias, «Maestro de Philosophia, y Professor de Mathematicas». Anunciada en 1738, parece que su autor era también astrólogo si a él se refiere el autor de la «Vida, y sucessos del astrologo Don Gomez Arias / escrita por el mismo» publicada en Madrid en 1744. El santo galo fue beatificado el 18 de mayo de 1716 y canonizado por Clemente II en el decreto del 5 de abril de 1736 .

En el mismo año, la Gaceta publica un anuncio de «La Relación en prosa y verso de las fiestas que en el Convento de Capuchinos de San Antonio del Prado se celebraron los dias 2, 3 y 4 de Febrero por la Beatificacion del Beato San Joseph de Leonisa de la misma Orden». El santo capuchino (1556-1612) fue canonizado unos cuantos años después, el 29 de junio de 1746. En este caso la obra forma parte de la bien conocida estrategia de publicaciones hagiográficas que tienen como meta suministrar materiales en los procesos de canonización.

Del popular San Roque, la Gaceta anuncia en 1741 la venta de una vida en forma de «Poema Historico Panegyrico» por don Don Antonio Tellez de Acevedo, «repartidor del número de receptores de esta corte y reales consejos». La obra titulada «Sacro sonoro canto que enlaza fervoroso el nacimiento vida y muerte de Sn. Roque» fue impresa por Gabriel Ramírez el mismo año en Madrid. El autor, conocido sobre todo por sus comedias, ya había publicado en 1727 una poesía religiosa: «Lyrica misteriosa y método contemplativo que a expresión de Láminas facilita el paso a la devoción, por seguir a el soberano Maestro, en el camino de su Sacratissima Passion», obra con 31 grabados que seguía el método contemplativo de San Ignacio de Loloya donde las imágenes tenían un papel importante. También de 1741 es el anuncio del «Romance Mystico, verdadero Retrato de la Vida, y Virtudes del V. P. M. Fr. Simon de Roxas, del Orden de la Santissima Trinidad de Calzados, escrito por un Religioso de la misma Orden». El santo español había sido declarado venerable unos cuantos años antes, el 25 de Marzo de 1735 por Clemente XII (su beatificación tendrá lugar en 1766 y su canonización en 1988).

Además de los poemas relacionados con canonizaciones, hay también anuncios de poemas redactados con motivo de traslaciones de reliquias. El primer anuncio de esta categoría es el «El Certamen Poetico, que se celebró en la Colocacion del Cuerpo de S. Juan de Mata, en la Iglesia de los Trinitarios Descalços». Obra anónima, se anuncia el 11 de agosto de 1722. El texto se relaciona con las fiestas que la propia Gaceta relata de la manera siguiente:

El dia 23 los Padres Trinitarios Calçados trasladaron las Insignes Reliquias del Huesso, de un brazo, y de una Costilla entera del Cuerpo de su patriarca, 
y Fundador S. Juan de Mata, los quales que ha mandado el Papa se les entreguen, como justa, y proporcionada división del Cuerpo del Santo, entre las dos familias de Calçados, y Descalços, los quales se trasladaron en una preciosa Urna de plata, fabricada con gran primor, la qual se conduxo con una Solemne Procesion General, que se formo en la Parroquial de San Pedro, y termino en la Iglesia de dichos Padres Trinitarios Descalços, a que concurrio toda la Grandeza, y Embaxadores, combidados por el señor Duque de Osuna, que llevo el Estandarte, Religiones, Comunidades, Cabildo y Villa de Madrid.

Una vez más, notamos que el plazo entre el acontecimiento y su publicación es muy breve. De Miguel de Reina Zevallos, autor mencionado anteriormente por su "Elocuencia del silencio», es la obra anunciada en 1750: «Historico-Sacro Poema á la Vida de Santa Casilda, Reyna que fue de Toledo» cuyo título completo, según reza la edición madrileña de 1727 , es «Histórico-sacro poema/en octavas reales/la prodigiosa phenix/ de la gracia/hija de el sol de justicia christo/cuya vida renace a nuevo ser, desde el monumento/de la Antigüedad, al ardiente eftudio de las Mufas: por vna, la mas inferior en el numen, aunque heroyca en el afeito que profefso:/A la esclarecida virgen/santa casilda/reyna que fue del reyno de Toledo/Águila grande, que bolo al desierto/ desde el Trono, para elevarse al Supremo de beatíficas delicias/defde el terrible Defíerto de rígidas afperezas». Es una obra postuma del R. P. Fr. Pedro de Reynosa, «Religiofo Capuchino de nueftro Serapbico P. S. Francifco, hijo de esta Provincia de Caftilla-, ExLector de theologia, Difinidor que fue en ella, y Guardian, que avia sido, del Convento de San Antonio de Capuchinos de esta Corte» que saca a luz «D. Francisco de Olivera y Sena, de orden y a expensas de la Excelentísima Señora Doña María Leonor Davila López de- Zuñiga, Marquefa de Loriana, \&c. por la gran devoción que tiene á la Santa y especial eftimacion que hizo de el Autor». Quizás la publicación de este texto se deba al hecho de que después de los traslados de los restos del cuerpo de santa Casilda desde su primitiva sepultura cavada en la roca donde pasó los últimos años de su vida como ermitańa en los lagos de San Vicente, junto al lugar del Buezo, hasta la catedral de Burgos en 1601, se inauguró en 1750 un nuevo altar en la nave mayor. De la popularidad de la santa son buen testimonio, además de las conocidas obras de los siglos anteriores -el yacente de Diego de Siloé de la catedral de Burgos y los lienzos de Zurbarán ${ }^{27}-$, los numerosos grabados ${ }^{28}$

27. Tres versiones por lo menos: la del Museo del Prado, la del Museo Thyssen-Bornemisza y la que pertenece a una colección privada en Barcelona.

28. Lista de elaboración propia a partir de los grabados y estampas que se conservan en la Calcografía Nacional de Madrid. 
que se imprimen en el siglo XVIII: el de Juan Moreno Tejada que lleva la siguiente inscripción: «Especialísima abogada de fluxos de sangre y esterilidad de mugeres / A devoción de su Congregación establecida en la Parroquial de S. Vicente Martyr de dicha Ciudad»; el de Francisco Ugena con esta inscripción: «Santa Casilda Virgen. Se venera en el Rl Colegio de Niños desamparados de esta Corte», los de José Castro, Salvador Carmona, Fray Tomás de Santa Ana (grabado en Roma) y Francisco Muntaner. También la santa fue objeto del importante fresco de la catedral de Toledo realizado por Francisco Bayeu y Subías en 1779, más bien relacionado con el tema de la Caridad que con el más tradicional de la «abogada de fluxos de sangre y esterilidad de mujeres».

Por último, añadimos en este apartado un anuncio que no es de canonización o de traslado de reliquias de santos sino de inauguración de un retablo. La «Sagrada métrica lid que al impulso de seis Toques alentados desde la cumbre de Parnaso hizo mystico alarde del triunfo, que en festivo Culto de Sta Ma de Jesus, cantó el amor con el ingenio en las Fiestas, que el Convento de S. Diego de Alcalá celebró nueve días en demostracion gozosa de ver colocado un Retablo nuevo / compuesto y ordenado todo por Joaquin de Aguirre vecino de la Corte» se anunció en 1730. El retablo vendría a completar el conjunto de los que adornaban las numerosas capillas del convento, donde la capilla de mayor prestigio era la de San Diego con su retablo costeado por el propio Felipe IV, que sentía especial devoción por el santo. La obra, un voluminoso tomo que supera las quinientas páginas en cuarto, fue impresa en Alcalá por Joseph Espartosa, «Impressor de la Universidad», en 1730. En el título completo se menciona que estas fiestas fueron celebradas por el «Convento de S. Diego de Alcala [...] por espacio de nueve días». El jesuita Joaquín Javier de Aguirre también tomó parte en debates sobre poesía clásica como lo sugiere su obra «El Principe de los poetas Virgilio mantenido en su soberanía entre las pretensiones de Lucano, apoyadas por... Fr. Benito Geronymo Feyjóo... en el tomo quarto de su Theatro, y en el suplemento á dicho tomo/ Respuesta del padre Joachin Xavier de Aguirre de la Compañia de Jesus ... a Carta del Señor D. Joseph Borrul», impresa en Madrid en 1744.

En síntesis, los datos que proporcionan las portadas permiten establecer, y era de esperar, que los autores son mayormente eclesiásticos, y que los miembros del clero regular dominan el conjunto con jesuitas, trinitarios descalzos, jerónimos, franciscanos y benedictinos. Los autores del clero regular suelen ser canónigos. En cuanto a los seglares, para tres de ellos no tenemos datos: los demás son un noble titulado, un alférez de marina, un abogado, 
un astrólogo «Maestro de Philosophia, y Professor de Mathematicas» y un «repartidor del número de receptores de esta corte y reales consejos» ${ }^{29}$.

Otra característica importante es que el calendario de acontecimientos relacionados con el culto a los santos -canonizaciones, beatificaciones, traslados de reliquias, inauguración de retablos, etc.- proporciona un amplio abanico de ocasiones para que un nutrido grupo de autores se apresure en redactar y publicar poemas, en algunos casos por encargo de particulares o instituciones, en otros por cuenta propia. La Gaceta solía anunciar rápidamente el nuevo impreso mientras los acontecimientos permanecían presentes en las memorias del público: el plazo entre edición y anuncio suele ser inferior a un ańo ${ }^{30}$.

Entre las diversas manifestaciones -fiestas, misas, etc.- que acompañaban estas celebraciones que duraban varios días (hasta nueve días como revela la portada del impreso dedicado al retablo del convento de San Diego en Alcalá), la poesía acostumbraba ocupar un lugar privilegiado. Eran frecuentes los certámenes que se organizaban en los actos y su posterior impresión. Inserta en estos actos de sociabilidad oral, se convertía luego en lecturas ejemplares para un amplio público de fieles cuya religiosidad radicaba en gran parte en un constante culto a los santos. El último elemento que destacaremos es la importancia de las reediciones de poesías sagradas de los grandes autores del Siglo de Oro -Lope de Vega, Calderón de la Barca, etc.-, en su totalidad o en partes escogidas.

\section{II.2.2 Pasión de Cristo: versos e imágenes}

Los escasos -comparados con otros temas- anuncios de poemas sobre Jesucristo presentan sin embargo gran interés porque permiten evidenciar dos formas de gran difusión de la poesía: la poesía con ilustraciones y los juegos entre poesía e imagen (laberintos, caligramas, etc.).

En la portería del convento del Carmen Calzado de Madrid se vendía la «Escena de Descendimiento de la Cruz» de don Joseph Belbia cuyo anuncio se publicó en 1726. Las cofradías del Descendimiento de la Cruz eran importantes (en Cuenca, León, etc.) y atestiguan este fervor por la Pasión de Cristo. También el tema había sido tratado en el teatro del siglo XVII y justo un año antes se había impreso el auto sacramental titulado «Descendimiento del Sacro Cuerpo de nuestro Redemptor de la Cruz, el Viernes Santo en la tarde» de Juan de Mójica.

29. Cayetano Alberto de la Barrera y Leirado, op. cit., p. 390.

30. Sobre estos aspectos, es interesante el artículo de Inmaculada Osuna, «Justas poéticas en Granada en el siglo XVII: materiales para su estudio», Criticón, 2004, n 90, p. 35-77. 
Una de las obras con más anuncios en la Gaceta tiene por tema el Vía Crucis. El «Aviso de una grave enfermedad, y un curioso Via-crucis, en verso, para contemplar la pasion y muerte de Christo ntro. Bien en su dolorosa Pasion» se anuncia el 24 de marzo de 1744, el 9 de marzo de 1745, el 28 de febrero de 1747 , el 12 de marzo de 1748 y el 25 de febero de 1749. En el primer anuncio se indica que es un «Aviso piadoso á una grave enfermedad, y un curioso Via Crucis, en Verso"; en los siguientes anuncios sólo se menciona el Vía Crucis. En los dos últimos anuncios, parece que la edición se enriqueció con láminas ${ }^{31}$ : «El Vía Crucis en verso, con Laminas de todas las Estaciones que anduvo Christo...». Esta obra corresponde a la modalidad del libro religioso ilustrado con grabados que venía a completar la amplia oferta de estampas sueltas. Asociar imagen y texto era habitual práctica como lo confirma la obra de Pablo Minguet - «Estampita nueva de medio pliego, que es un Nacimiento de N. S. Jesu-Christo, con un Labyrinto de cinco mil y quinientas Quintillas, todas en alabanza del Nińo Dios»anunciada en 1745. La obra de Pablo Minguet más conocida y anunciada en la Gaceta es su «Noble arte de danzar a la francesa, y española adornado con LX láminas finas». En su análisis de la obra, Clara Rico Osés indica ${ }^{32}$ :

En cuanto a Pablo Minguet e Yrol, tampoco se tienen demasiados datos sobre su vida. Se autodefine como un «grabador de sellos, láminas, firmas

31. La bibliografía sobre la estampa religiosa es abundante. Además de los estudios de Julio Caro Baroja, 1985, Las formas complejas de la vida religiosa (Religión, sociedad y carácter en la España de los siglos XVI y XVII), Barcelona, Sarpe, 1985 y de Javier Portús Pérez, Jesusa Vega, La estampa religiosa en la España del Antiguo Régimen, Fundación Universitaria Española, 1998, son de señalar los trabajos siguientes: María Cruz De Carlos, Pierre Civil, Felipe Pereda y Cécile Vincent-Cassy, La imagen religiosa en la Monarquía hispánica. Usos y espacios, Madrid, Casa de Velázquez, 2008; Jesusa Vega González, «Irracionalidad popular en el arte figurativo español del siglo XVIII», Anales de literatura española, n 10, 1994, p. 237-273; Arte y devoción. Estampas de imágenes y retablos de los siglos XVII y XVIII en iglesias madrileñas, Madrid, 1990, Calcografía Nacional; Concepción Alarcón Román, «La iconografía religiosa en el siglo XVIII», Revista de Dialectología y Tradiciones Populares, n 45, 1990, p. 247-277; Juan Carrete Parrondo, «La ilustración de los libros: siglos XV al XVIII», en Historia ilustrada del libro español. De los incunables al siglo XVIII, Madrid: Fundación Germán Sánchez Ruipérez y Pirámide, 1994, p. 271-359; Salvador Rodríguez G. Becerra, «Piedad y vida religiosa en la Corte durante el siglo XVIII", en El Real Sitio de Aranjuez y el arte cortesano del siglo XVIII, Madrid, Comunidad de Madrid, 1987, p. 191-202; Carlos Álvarez Santaló, María Jesús Buxó i Rei, Salvador Rodríguez G. Becerra (coords.), La religiosidad popular, Barcelona, Anthropos, 2003, 3 vol., en particular el segundo volumen «Vida y muerte: La imaginación religiosa»; Jorge Jesús Cabrerizo Hurtado, «Devoción personal. El grabado religioso y la democratización del arte», Alonso Cano. Revista Andaluza de Arte, n 7, 2005.

32. Clara Rico Osés, «La contradanza en Espańa en el siglo XVIII: Ferriol y Boxeraus, Minguet e Yrol y los bailes públicos», Anuario Musical, 2009, n 64, p. 191-214. 
y otras cosas» y fue discípulo de Juan Bernabé Palomino [...] Además de grabador fue teórico, escritor y editor y desarrolló aspectos muy dispares; publicó obras de temas lúdicos (Juegos de manos ó sea Arte de hacer diabluras y juegos de prendas...), religiosos (Meditaciones para el Santo Sacrificio de la Misa...), musicales (tratados de música instrumental como Reglas y advertencias generales que enseñan el modo de tañer todos los instrumentos...) y de danza.

El «Laberinto» de Minguet es una de las formas -caligramas, acrósticos, romances mudos, etc.- que podía adoptar la poesía cuando quería ser objeto de recreo basado en una enigmática disposición tipográfica ${ }^{33}$.

La «Lira misteriosa para el camino de la passion: dispuesta en verso a contemplación de 30 láminas / por Antonio Téllez de Acevedo» editada en Madrid en 1727 y con 30 láminas y una portada grabadas en cobres por el importante grabador y tratadista Fray Mathias de Irala ${ }^{34}$ se anuncia dos veces: el 4 de marzo de 1727 y el 15 de febrero de 1729 . Ya hemos mencionado a Antonio Téllez de Acevedo en la parte dedicada a hagiografías (San Roque).

\section{II.2.3 Biblia y traducciones}

Dos obras se relacionan con la Biblia. La primera es la «Metrica historia sagrada, profana, y general de el mundo, sus tres primeras edades, sobre el libro de el Genesis que ofrece a los pies de la gloriosissima Virgen, baxo la Invocacion de nuestra Sra. de la Gracia, patrona, y tutelar de el Hospital Real, y General de Zaragoza, su autor don Bernabe Rebolledo de Palafox, Marqués de Lazán, regidor de dicho hospital, en cuya Real Casa se vende a beneficio de sus Pobres Enfermos ... en Zaragoza: por Juan Malo, Impressor del Hospital» cuyo anuncio se publicó en 1734, el mismo año de su edición. Lo obra consta, amén de las octavas de las tres primeras edades, de una serie

33. Sobre este tema, son importantes los trabajos de José María Díez Borque (ed), Literatura de la celebración, verso e imagen en el barroco español, Madrid, Madrid Capital Europea de la Cultura, 1992; Imagen en el verso: del Siglo de Oro al siglo XX, catálogo de la exposición de la Biblioteca Nacional, marzo-mayo 2008; el catálogo Verso e imagen. Del Barroco al Siglo de las Luces, Madrid, Comunidad de Madrid, 1993, Víctor Infantes, «La presencia de una ausencia. La emblemática sin emblemas», en Sagrario López Posa (ed.), Literatura emblemática hispánica. Actas del I Simposio Internacional de Literatura emblemática Hispánica (La Coruña, 1994), La Coruña, Universidade da Coruña, 1996, pp. 93-109. Fernando R. de la Flor, «El régimen de lo visible: figuras de la poesía visual», en Emblemas. Lecturas de la imagen simbólica, Madrid, Alianza, 1995, Alianza Forma 131, pp. 209-232.

34. Antonio Bonet Correa, Vida y obra de fray Matías de Irala, grabador y tratadista del siglo XVIII español, Madrid, ediciones Turner, 1979. 
de poemas: epigramas y elegías en latín, romances y canciones en castellano. El texto de la portada revela lo que motivó al segundo marqués de Lazán a publicar su texto: hacer una obra pía para colectar fondos para el Hospital que dirigía. No eran pues sólo el afán de fama, el proselitismo religioso o la ejemplaridad moral los razones que animaban a los poetas a publicar sus obras.

Curiosamente el segundo anuncio relacionado con la Biblia es también obra de un noble titulado, Vicente Vacallar y Sanna, Marqués de San Felipe. Su obra - «Los Tobias, su vida / escrita en octavas por D. Vicente Bacallar y Sanna... Manda imprimir, y la saca á luz con notas marginales... D. Joseph de Solis Gante y Sarmiento, Marqués de Castelnovo...» viene anunciada en 1747 con una indicación interesante «historia sagrada, escrita en 500 octavas rimas castellanas» que nos revela su forma. El Marqués de San Felipe (16691726) fue partidario de Felipe V en la Guerra de Sucesión y desempeñó cargos políticos y militares importantes. Su Monarquía hebrea cuya primera edición salió en 1719 tuvo gran éxito y fue traducida al francés y publicada en La Haya en 1727. Parece que «Los Tobias» forman el tercer tomo de esta obra.

Una de las obras con más anuncios es la «Traduccion en verso de los Hymnos, y Sequencias del Breviario, y Missal Romano, y de los Santos de la Orden de la Merced» cuya primera mención en la Gaceta es del 19 de mayo de 1744. Los anuncios del 7 de julio de 1744 y del 19 de noviembre de 1748 dan el mismo título. Sin embargo, el anuncio del 3 de julio de 1747 indica cuál es el público destinatario: «muy util para las Religiosas, y personas que rezan el Oficio Divino, y no saben el Latin». El anuncio del 9 de abril de 1748 añade «con las Notas para la inteligencia de las cosas que contienen, poco sabidas». Obra para facilitar la oración de las religiosas y demás fieles que pone a su alcance con su traducción al castellano, el texto original en latín. Su autor es Fr. José Beltrán, mercedario, maestro y definidor de la provincia de Castilla en el año $1743^{35}$. La obra se publicó en Madrid en 1744 y en $8^{\circ}$.

\section{II.2.4 Poesia y religiosidad}

Es seguramente la categoría menos definida. Un primer tipo de obras son las que tratan del arrepentimiento del pecador. En 1734, la Gaceta anuncia

35. La identificación del autor, dado que en el catálogo de la Biblioteca Nacional no se indica, se encuentra en José Antonio Garí y Siumell, Biblioteca Mercedaria: ó sea Escritores de la celeste, real y militar Órden de la Merced, redencion de cautivos, Barcelona, 1812. 
unos «Suspiros Métricos, que embia un Pecador, reconocido de el horror de su culpa, al Tribunal de la Divina Misericordia». El autor, predicador y catedrático de Humanidades y Griego en la Universidad de Valladolid, publicó también (pero no anunciada en la Gaceta) una «Fuente de la elegancia en tres tratados. Sintaxis elegante. Metrologia o método claro para saber brevemente todo género de versos latinos. Epistolopeia: método fácil de escribir cartas ..." que sí se menciona en el Diario Pinciano: «Sintaxis castellana de Francisco Guerra, escrita en verso» ${ }^{36}$.

La obra de Francisco de la Justicia y Cárdenas, quizás un religioso franciscano ${ }^{37}$ que se anuncia en 1750 es de idéntica temática: «Expresiones Catholicas Metricas, que descrive un pecador arrepentido, exclamando al Tribunal de la Divina Misericordia». Se publicó en 1749 y sólo constaba de 17 páginas. El autor es conocido por los numerosos "piscatores» que publicó: Lazarillo de los ciegos de esta Corte, El Gran Piscator de Madrid, El Piscator de Don Quijote, Las lavanderas del Manzanares o Gran Piscator del Río, Los aguadores de la fuente de la Puerta del Sol o Piscator de Mariblanca. De carácter ejemplar también sería sin duda la «Reflexion mystica, que al desgraciado tragico sucesso de haverse muerto de repente un venerable anciano el dia 4. de Marzo en la Iglesia de S. Jorge, hace don Francisco Cuadros en un Romance heroico». No hemos encontrado dato alguno sobre este autor. El anuncio es de 1744.

Varias obras incluyen textos en prosa y verso. Es el caso de el «El Philosopho Sueco, y Lutherano desengañado: Pensamientos, y Reflexiones Criticas del Conde de Oxenstirn, con mucha erudicion, y alguna Poesía, traducido del Francés al Castellano por Boona» anunciado en 1745. Entre los motivos que animaron el traductor, Benito Jacinto de Novoa y Lisasueta, a publicar la obra se hallaría seguramente el deseo de publicar las obras de un autor de tan ejemplar conversión al catolicismo («Lutherano desengañado»). En el título francés - «Pensées de M. le comte d'Oxenstirn sur divers sujets, avec les réflexions morales du même auteur»- no había ninguna referencia a su conversión. En el «Prólogo del traductor Novoa» de la edición madrileña de 1837 a cargo de Justino Mantuano, se encuentran datos biográficos interesantes pero también la explicación de la presencia de textos en verso:

El nombre de Oxenstirn es muy conocido, porque Axel de Oxenstirn lo ha inmortalizado con los importantes servicios que hizo á la corona de Suecia; y

36. Irene Vallejo González, "La vertiente literaria en el "Diario Pinciano"», Castilla: Estudios de literatura, 1980, n 1, p. 125-134. La mención de la Sintaxis en la p. 133.

37. P.-J Guinard, «Remarques sur un ouvrage interdit: Lo que no se ha escrito, de Francisco de la Justicia y Cárdenas (1749)», Bulletin Hispanique, 66, n 3-4, 1964. pp. 349-358. 
la historia de la larga guerra de los suecos en Alemania, que se acabó con la paz de Wesfalia, hace mención de él muy frecuente y honrosamente. Su sobrino el conde de Oxenstirn se hizo conocer por sus viages en casi todos los reinos de Europa: su nombre, su entendimiento cultivado con la lectura, su buen humor y la facilidad de poderse esplicar en muchas lenguas le introducían en las mejores sociedades [...]. En sus viages abrazo la religion católica [...] La tristeza sucedió á aquella alegría tan conforme á su complexión viva, y una soledad involuntaria al principio, y despues gustosa, le puso en estado de reflexionar mas seriamente de lo que lo habia hecho en el ardor de una juventud voluptuosa. Habiendose aplicado á la lectura, los pocos libros que habia visto antes de su retiro no dejaron de suministrarle diversos ejemplos y buenos fragmentos de poesía, de que se acordaba, sirviendose de ellos para adornar sus reflexiones conforme las escribía. Habiendo oido un librero hablar de los pensamientos, que el conde de Oxenstirn recogía, procuró tener una copia, y los imprimió. El nombre del autor, conocido en las mas de las cortes, escitó la curiosidad del público.

Añade Justino Mantuano: «La edición que hemos reformado y anotado, sin fecha ni nombre de impresor, es del año de 1745; solo dice se vendía en casa de Mr, Symond, Puerta del Sol, frente de los peineros». La primera edición es de 1742 y parece que la redacción se debe a Antoine-Augustin Bruzen de la Martinière; la segunda del mismo ańo fue editada por «Les libraires associés», ambas en París.

Algunas poesías se centraban en los momentos más intensos del calendario religioso como los tiempos de cuaresma. Ínigo de Oyanguren Cavallero publicó en 1739 una obra para este fin: «Quaresma poetica distribuida por todos los dias de la Quaresma, en un Soneto, y veinte Coplas de Romance Castellano cada Feria», impreso en Madrid por Joseph González. La obra tuvo varios anuncios en $1743,1744,1745$ y 1747 . En el de 1744 , se precisa que la "Quaresma poetica, distribuída por todos los dias de Quaresma, y Ferias» abarca «desde el Miercoles de Ceniza, hasta el Domingo de Pasqua». La obra en latín del P. Juan Ignacio de Larralde anunciada en la Gaceta de 1750 se relaciona asimismo con el calendario litúrgico. En la edición de la Imprenta de Pons y C. ${ }^{\text {a de }} 1851$ del Índice general de los asuntos del novísimo Año Cristiano del P. Juan Croisset se menciona en la página 206 la obra del P. Larralde:

Al principio del de 1750 se publicaron en Madrid dos tomos del P. Juan Ignacio de Larralde de nuestra Compañía, escritos en lengua latina con este titulo: Annus Sanctus poetice concinnatus, in quo omnia Sanctæ Ecclesicæ Festa, tum de tempore, tum de Sanctis, brevi, perspicua methodo, et multigena versum varietate celebrantur. In duas divisus partes, quarum 
prima agit de festis movilibus, seu de propio tempore: secunda vero de his quæ certis sunt alligata diebus. Quiere decir: «Año Santo, dispuesto en verso latino, en el cual se celebran con breve y claro método, y con mucha variedad de metros todas las fiestas, que solemniza la santa Iglesia, así las que se llaman del tiempo, como las de los Santos. Divídese en dos partes: la primera contiene las fiestas del tiempo, ó las movibles; la segunda trata de las fijas.»

De semejante temática y del mismo modo en latín es el «Persacilis ars chronologica, con la qual, en virtud de unos versos ingeniosos, en muy pocos dias se puede saber, y conservar en la memoria toda la Chronologia Sagrada y Eclesiastica» anunciado en 1747. Su autor, Lucas Ventura Bueno, era cura de Santa María de Castenda, en el Arzobispado de Santiago y «Examinador Synodal». Ambas obras difieren de las anteriormente evocadas puesto que la barrera del idioma limita su lectura a un público que sin ser únicamente de especialistas fuera capaz de leer en latín.

\section{II.2.5 Obras completas}

Nos quedan por examinar antes de concluir algunos anuncios que mencionan la edición de obras completas. En 1722, se anuncian las «Obras poéticas póstumas que a diversos asuntos escribió el maestro Manuel de León Marchante [...]; divididas en tres clases, sagradas, humanas y cómicas». La portada revela que fueron publicadas por "un su aficionado» $y$ que el Maestro León Marchante (1631-1680) desempeñaba toda una serie de cargos "Comisario del Santo Oficio de la Inquisición, Capellan de fu Mageftad, y del Noble Colegio de Cavalleros Manriques de la Univerfidad de Alcalá, Racionero de la Santa Iglesia Magistral de San Julio y Pastor de dicha ciudad». El primer tomo se publicó en 1722, el segundo en 1733, ambos a costa de Fernando Monge.

Otras «Obras poéticas posthumas» son las de Pedro Scotti de Agoiz (fallecido hacia 1730) anunciadas en los meses de agosto y de septiembre de 1735. El autor fue corregidor de Logrońo, Calahorra, Alfaro, Guadix y Baza, cronista general de los reinos de Castilla, miembro de la Real Academia Española y señor de las villas de Somontín y Fines en la provincia de Almería. La obra editada por su hijo, el también poeta Francisco Scotti Fernández de Córdoba, comprende dos comedias y dos zarzuelas. Sin embargo si el título es exacto, las obras poéticas podrían ser otras obras de Pedro Scotti como su romance apologético de Santa Juana Inés de la Cruz y un poema sobre la canonización de San Juan de Dios. 
Más famoso es don Joseph Perez de Montoro ${ }^{37}$ cuyas «Celebres, y deseadas Obras Lyricas, Humanas y Sagradas/ nueva impresion en dos tomos» se anuncian en 1736. Como también lo es «El Discreto de Palacio», Antonio Hurtado de Mendoza, importante dramaturgo de la primera mitad del siglo XVII cuya edición de sus «Obras líricas y cómicas, divinas y humanas» en 1728 es considerada como una de las mejores recopilaciones editadas hasta aquella fecha. En la portada se advierte que las obras ofrecen la «celestial ambrosía del admirable poema sacro de María Santísima» y que se trata de una «Segunda impression, corregidas y enmendadas de los muchos yerros que en la primera havia cometido el descuido de la imprenta, añadidas algunas obras ... se tienen por ciertas, y verdaderas del autor ... / por mano de Don Ambrosio Cano».

La última obra completa es una de las pocas obras de autores extranjeros. La Madre Maria do Ceo (1658-1752), «Religiosa Francisca de Lisboa, y Abadesa del Monasterio de la Esperanza de Lisboa», fue una autora de obras de teatro de temática religiosa como su Triunfo del Rosario «repartido en cinco autos "y publicado en 1740 en Lisboa. La Gaceta anuncia en 1745" Las Admirables Obras, en prosa, y verso» de María do Ceo que podría ser el segundo tomo de sus obras impreso por Antonio Marín en 1744 cuya portada seńala que son «Corregidas de los muchos defectos de la edición Portuguesa, e ilustradas con breves Notas por el Doct. D. Fernando de Setién Calderón de la Barca». A pesar de ser portuguesa, María do Ceo dominaba perfectamente el idioma castellano.

\section{Conclusión}

Evidentemente la visión que damos de los anuncios de impresos en la Gaceta es muy incompleta como lo evidencian las cifras: era imposible utilizar los 4679 anuncios publicados entre 1697 y 1750. Sin embargo, el

38. Varios trabajos de Alain Bègue tienen por objeto a este poeta: «La primera réplica en los villancicos dialogados de José Pérez de Montoro", Criticón, 2001, n 83, pp. 133-146; Recherches sur la fin du Siècle d'Or espagnol: José Pérez de Montoro (1627-1694), Toulouse, Université de Toulouse-Le Mirail, 2004.Tesis doctoral inédita; "Aproximación a la lengua poética de la segunda mitad del siglo XVII: el ejemplo de José Pérez de Montoro», en Investigaciones recientes sobre la literatura del Siglo de Oro. Homenaje a Julián Durán. Seminario de la Casa de Velázquez (Madrid, 3 y 4 de mayo de 2004), Alain Bègue, Agnès Delage y Christel Lapisse (eds.), Madrid/Toulouse, Casa de Velázquez/Instituto Cervantes/Presses Universitaires du Mirai, Criticón, n 97-98, 2006, pp. 153-170; «Los límites de la poesía epidíctica: la poesía jocoseria de José Pérez de Montoro», en La poesía burlesca del Siglo de Oro. Nuevas perspectivas, Alain Bègue y Jesús Ponce Cárdenas (eds.), Madrid/Toulouse, Instituto Cervantes/Presses Universitaires du Mirail (Criticón, 100), 2007, pp. 143-166. 
análisis cuantitativo permite dibujar el lugar que ocupa el anuncio poético en este conjunto. La Gaceta revela la progresiva toma de conciencia de la importancia de la publicidad como ocurre con la prensa naciente: valga como ejemplo el hecho de que el Mercurio histórico y político que cuyo primer ejemplar es de1738, publicó, entre 1741 y 1794, unos 760 anuncios para informar que estaba a la venta. La relativa rapidez con que se anuncian las obras que salen a la luz-muchas en menos de un año- es un buen indicio del papel publicitario que desempeñan los anuncios.

El botón de muestra de los anuncios de poesía religiosa permite ver asimismo la importancia de las obras de literatura ocasional y de circunstancias. Por otra parte, ofrece esta muestra una idea de la variedad temática y formal de la poesía religiosa. También nos habla de la sociabilidad en la que se crea (Academias, certámenes, etc.), se escucha y se lee, de sus funciones y públicos destinatarios. No obstante, la delimitación del impreso poético se podría ampliar puesto que muchas obras de teatro llevan, en parte por lo menos, formas poéticas. También se podría ensanchar a la segunda mitad del siglo XVIII y profundizar analizando los anuncios poéticos de otros periódicos, madrileños y provinciales conforme van apareciendo. Los estudios por venir tendrían que sistematizar mucho más la tipología y sociología de los autores de poesías, buscar también qué papel desempeña la creación de sus obras, cuáles son los motivos que les empujan a publicar. Por fin, los libreros e impresores que mencionan los anuncios son datos que de momento dejamos sin estudiar. Además de completar lo que sabemos de la red de difusión del impreso sería importante ver cómo definen su estrategia publicitaria en la Gaceta. 
Cuadro $n^{\circ} 1: \mathrm{N}^{\circ}$ de anuncios de impresos por año

\begin{tabular}{|c|c|c|c|c|c|}
\hline Años & Total anuncios & Años & $\begin{array}{c}\text { Total } \\
\text { anuncios }\end{array}$ & Años & Total anuncios \\
\hline 1697 & 4 & 1726 & 83 & 1758 & 390 \\
\hline 1698 & 9 & 1727 & 223 & 1759 & 137 (a) \\
\hline 1699 & 4 & 1728 & 238 & 1760 & 223 \\
\hline 1700 & 7 & 1729 & 178 & 1761 & 346 \\
\hline 1701 & 12 & 1730 & 207 & 1762 & 380 \\
\hline 1702 & 4 & 1731 & 154 & 1763 & $20(\mathrm{a})$ \\
\hline 1703 & 5 & 1732 & 110 & 1764 & 292 \\
\hline 1704 & 5 & 1733 & 103 & 1767 & 422 \\
\hline 1705 & 5 & 1734 & 166 & 1768 & 301 \\
\hline 1706 & 5 & 1735 & 163 & 1769 & 261 \\
\hline 1707 & 12 & 1736 & 133 & 1770 & 268 \\
\hline 1708 & 9 & 1737 & 125 & 1771 & 247 \\
\hline 1709 & 7 & 1738 & 172 & 1772 & 248 \\
\hline 1710 & 1 & 1739 & 129 & 1773 & 163 \\
\hline 1711 & 11 & 1740 & 140 & 1774 & 216 \\
\hline 1712 & 17 & 1741 & 172 & 1775 & 227 \\
\hline 1713 & 22 & 1742 & 146 & 1776 & 214 \\
\hline 1714 & 16 & 1743 & 149 & 1777 & 280 \\
\hline 1715 & 23 & 1744 & 204 & 1778 & 488 \\
\hline 1716 & 21 & 1745 & 152 & 1779 & 396 \\
\hline 1717 & 37 & 1746 & 138 & 1783 & 521 \\
\hline 1718 & 27 & 1747 & 142 & 1791 & 1416 \\
\hline 1719 & 46 & 1748 & 151 & 1792 & 712 \\
\hline 1720 & 35 & 1749 & 140 & 1793 & 1566 \\
\hline 1721 & 62 & 1750 & 229 & 1794 & 790 \\
\hline 1722 & 68 & 1751 & 155 & 1807 & 2022 \\
\hline 1723 & 83 & 1752 & 223 & Total & 19017 \\
\hline 1724 & 86 & 1753 & 228 & & \\
\hline 1725 & 89 & 1754 & 275 & & \\
\hline 1726 & 83 & 1755 & 374 & & \\
\hline 1727 & 223 & 1756 & 314 & & \\
\hline 1728 & 238 & 1757 & 223 & & \\
\hline
\end{tabular}


BULLETIN HISPANIQUE

Cuadro n 2 : Anuncios de 1697 a 1750

\begin{tabular}{|c|c|c|c|c|c|c|c|}
\hline Años & $\begin{array}{c}\text { Total } \\
\text { anuncios }\end{array}$ & $\begin{array}{l}\text { Anuncios } \\
\text { poéticos }\end{array}$ & $\begin{array}{l}\% \text { Anuncios } \\
\text { poéticos }\end{array}$ & Años & $\begin{array}{c}\text { Total } \\
\text { anuncios }\end{array}$ & $\begin{array}{c}\text { Anuncios } \\
\text { poéticos }\end{array}$ & $\begin{array}{l}\% \text { Anuncios } \\
\text { poéticos }\end{array}$ \\
\hline 1697 & 4 & 0 & 0 & 1724 & 86 & 4 & 4,7 \\
\hline 1698 & 9 & 0 & 0 & 1725 & 89 & 2 & 2,2 \\
\hline 1699 & 4 & 0 & 0 & 1726 & 83 & 3 & 3,6 \\
\hline 1700 & 7 & 0 & 0 & 1727 & 223 & 5 & 2,2 \\
\hline 1701 & 12 & 0 & 0 & 1728 & 238 & 10 & 4,2 \\
\hline 1702 & 4 & 0 & 0 & 1729 & 178 & 8 & 4,5 \\
\hline 1703 & 5 & 0 & 0 & 1730 & 207 & 6 & 2,9 \\
\hline 1704 & 5 & 0 & 0 & 1731 & 154 & 2 & 1,3 \\
\hline 1705 & 5 & 0 & 0 & 1732 & 110 & 13 & 11,8 \\
\hline 1706 & 5 & 0 & 0 & 1733 & 103 & 4 & 3,9 \\
\hline 1707 & 12 & 0 & 0 & 1734 & 166 & 15 & 9,0 \\
\hline 1708 & 9 & 0 & 0 & 1735 & 163 & 11 & 6,7 \\
\hline 1709 & 7 & 0 & 0 & 1736 & 133 & 13 & 9,8 \\
\hline 1710 & 1 & 0 & 0 & 1737 & 125 & 7 & 5,6 \\
\hline 1711 & 11 & 0 & 0 & 1738 & 172 & 8 & 4,7 \\
\hline 1712 & 17 & 2 & 11,8 & 1739 & 129 & 6 & 6,0 \\
\hline 1713 & 22 & 0 & 0 & 1740 & 140 & 1 & 0,7 \\
\hline 1714 & 16 & 0 & 0 & 1741 & 172 & 7 & 4,1 \\
\hline 1715 & 23 & 0 & 0 & 1742 & 146 & 2 & 1,4 \\
\hline 1716 & 21 & 0 & 0 & 1743 & 149 & 8 & 5,4 \\
\hline 1717 & 37 & 0 & 0 & 1744 & 204 & 20 & 9,8 \\
\hline 1718 & 27 & 0 & 0 & 1745 & 152 & 15 & 9,9 \\
\hline 1719 & 46 & 1 & 2,2 & 1746 & 138 & 21 & 15,2 \\
\hline 1720 & 35 & 1 & 2,9 & 1747 & 142 & 12 & 8,5 \\
\hline 1721 & 62 & 2 & 3,2 & 1748 & 151 & 8 & 5,3 \\
\hline 1722 & 68 & 4 & 5,9 & 1749 & 140 & 3 & 2,1 \\
\hline 1723 & 83 & 1 & 1,2 & 1750 & 229 & 22 & 9,6 \\
\hline 1724 & 86 & 4 & 4,7 & Total & 4679 & 247 & 5,28 \\
\hline
\end{tabular}

